Portland State University

PDXScholar

1978

\title{
Germination, respiration and photosynthesis in seeds of dwarf mistletoe (Arceuthobium)
}

Steven Wayne Gustafson

Portland State University

Follow this and additional works at: https://pdxscholar.library.pdx.edu/open_access_etds

Part of the Biology Commons, and the Plant Sciences Commons

Let us know how access to this document benefits you.

\section{Recommended Citation}

Gustafson, Steven Wayne, "Germination, respiration and photosynthesis in seeds of dwarf mistletoe (Arceuthobium)" (1978). Dissertations and Theses. Paper 2735.

https://doi.org/10.15760/etd.2730

This Thesis is brought to you for free and open access. It has been accepted for inclusion in Dissertations and Theses by an authorized administrator of PDXScholar. Please contact us if we can make this document more accessible: pdxscholar@pdx.edu. 
AN ABSTRACT OF THE THESIS OF Steven Wayne Gustafson for the Master of Science In Biology presented July 31, 1978.

Title: Germination, Respiration, and Photosynthesis in seeds of Dwarf Mistletoe (Arceuthobium).

APPROVED BY MEMBERS OF THE THESIS COMMITTEE:

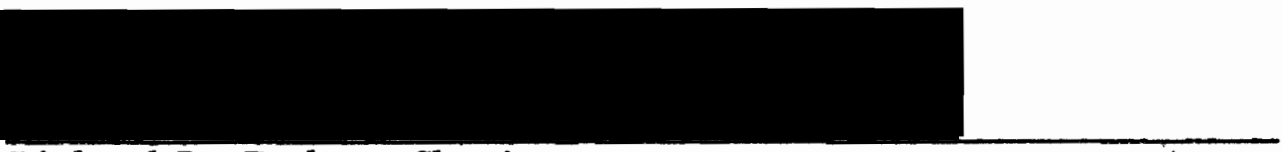

Richard D. Tocher, Chariman

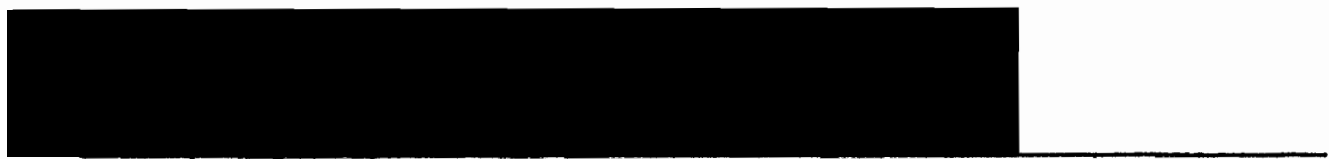

Robert 0. Tinnin

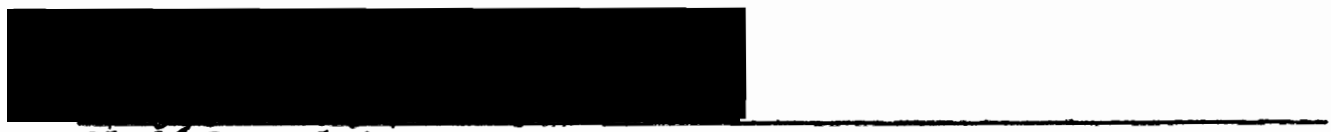

Clyde L. Calvin

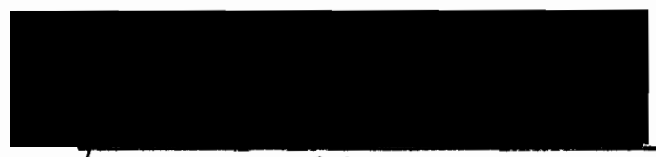

Horace $\mathrm{F}$. White

Germination, respiration, and photosynthesis in seeds of dwarf mistletoe (Arcenthobium) were studied. The effects of 1 hour soakings of seeds in aqueous solutions of 1,2 , or $3 \% \mathrm{H}_{2} \mathrm{O}_{2}$ or $1,2,3,4$, or $5 \%$ Chlorox on germination of seeds were tested. Germination rates for seeds from three consecutive years (1975-1977) were obtained. Germination rates varied widely. This variance transcended subtle changes in treatment. Pretreatment of seeds with Chlorox resulted in signifi- 
cantly lower germination rates than those of the control. Chlorophyll concentrations were determined for seeds and aerial shoot tissue of four species. Seeds of A, douglasii had the highest chlorophyll concentration $(0.39 \mathrm{mg} / \mathrm{g}$ fresh weight) while seeds of A. tsugense had the lowest concentration $\left(0.25 \mathrm{mg} / \mathrm{g}\right.$ fresh weight). Net $\mathrm{O}_{2}$ uptake by seeds of A. campylopodum in dark and in light was measured by manometric and polarographic methods. The mean values were $353 \mu \mathrm{ll} \mathrm{O}_{2} \mathrm{~g}^{-1} \mathrm{~h}^{-1}$ in the dark and $201 \mu 10_{2} g^{-1} h^{-1}$ in the light. The difference between these rates is apparently due to $\mathrm{O}_{2}$ evolution during photosynthesis. In light the seeds can fix $43 \%$ of the $\mathrm{CO}_{2}$ produced by respiration. Experiments in which seeds were exposed to ${ }^{14} \mathrm{CO}_{2}$ in light confirmed that the seeds are able to fix $\mathrm{CO}_{2}$. Extraction of seeds with ethanol showed that $97-99 \%$ of the incorporated ${ }^{14} \mathrm{C}$ was ethanol soluble. Ten to sixteen percent of the ethanol fraction was chloroform soluble while the rest was $\mathrm{H}_{2} \mathrm{O}$ soluble. Ion exchange separation of the $\mathrm{H}_{2} \mathrm{O}$ phase showed that $11-25 \%$ of ${ }^{14} \mathrm{C}$ activity was cationic, $15-29 \%$ anionic, and $53-67 \%$ neutral. 


\title{
GERMINATION, RESPIRATION AND FHOTOSYNTHESIS IN SEEDS \\ OF DWARF MISTLETOE (ARCEUTHOBIUM)
}

\author{
by \\ STEVEN WAYNE GUSTAFSON
}

A thesis submitted in partial fulfillment of the requirements for the degree of

\author{
MASTER OF SCIENCE \\ in \\ BIOLOGY
}

Portland State University

1978 
TO THE OFFICE OF GRADUATE STUDIES AND RESEARCH:

The members of the Comittee approve the thesis of

Steven Wayne Gustafson presented July 31, 1978

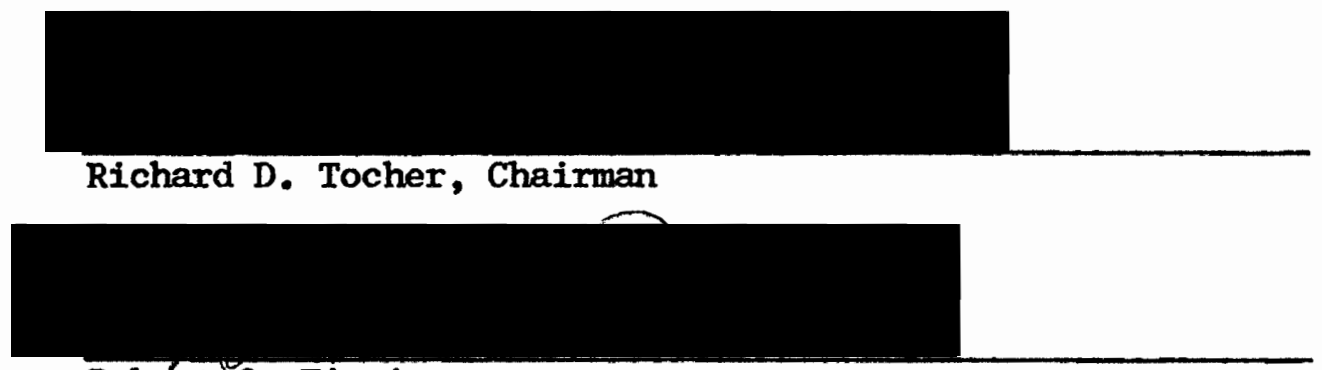

Robert 0. Timin

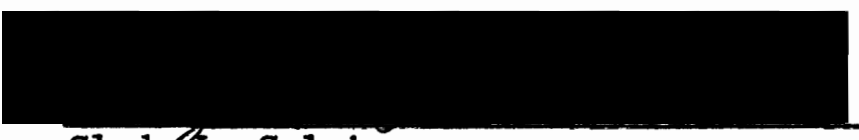

Clyde/L. Calvin

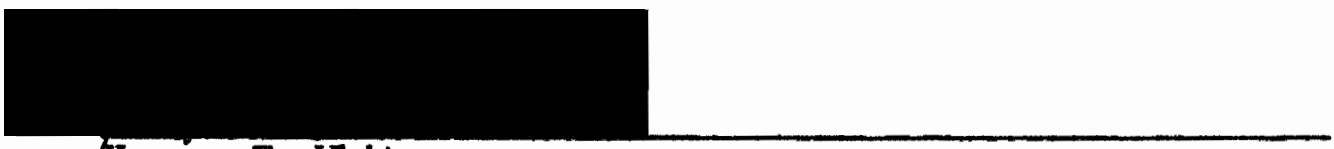

Horace F. White

\section{APPROVED :}

W. Hermarf Taylor, Jr. Head Department of Biology

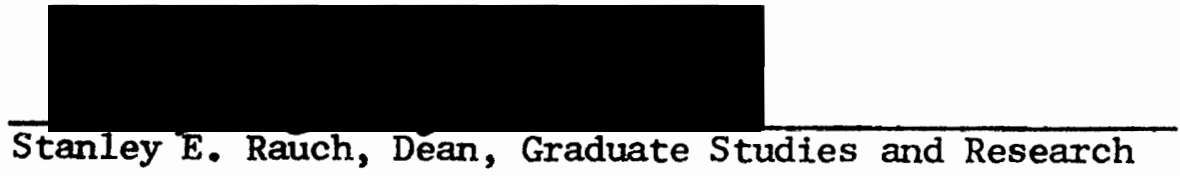




\section{ACKNOWLEDGMENTS}

The author wishes to express his appreciation for assistance given by the following individuals: Thesis committee members, Doctors Richard D. Tocher, Robert 0. Tinnin, Clyde L. Calvin, and Horace F. White for their advice in preparation of this manuscript; Dr. W. Herman Taylor and the Biology Department of Portland State University for financial assistance; Dr. Donald Knutson, U. S. Forest Service, for seeds and information generously provided; Peter Paquet for information and assistance; Paul Collins, for assisting in statistical aspects of this study; and my wife, Gayle, for her patience and effort in typing this manuscript. 
TABLE OF CONTENTS

PAGE

ACKNOWLEDGEMENTS . . . . . . . . . . . . iii

LIST OF TABLES . . . . . . . . . . . v v LIST OF FIGURES . . . . . . . . . . . vii

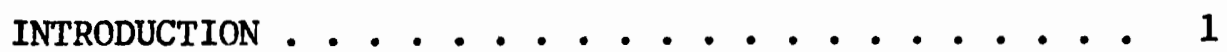
LITERATURE REVIEW .............. 3 MATERLALS AND METHODS . . . . . . . . . 7 RESULTS AND DISCUSSION . . . . . . . . . 18 CONCLUSION . . . . . . . . . . . . . . 39 APPENDIX ....................... 44 
LIST OF TABLES

TABLE

PAGE

I Collection Sites .................

II Germination Percentages for Seeds of $A_{0}$ campylopodum

Treated with $\mathrm{H}_{2} \mathrm{O} \ldots \ldots \ldots$

III Summary of Statistical Analysis of Germination Rates

for Seeds of A. campylopodum ..........

IV Germination of Seeds of A. $_{0}$ campylopodum pretreated

with Chlorox ............. 23

V Seed Chlorophyll Concentrations ......... 26

VI Aerial Shoot Chlorophyll Concentrations . . . . . 27

VII Summary of Statistical Analysis of Chlorophyll

Concentrations for Seeds and Aerial Shoot Tissue

of 4 Species of Arceuthobium ..........

VIII $\mathrm{O}_{2}$ Uptake by Seeds of A. campylopodum in Light and in

Dark Measured by Manometric Methods .......

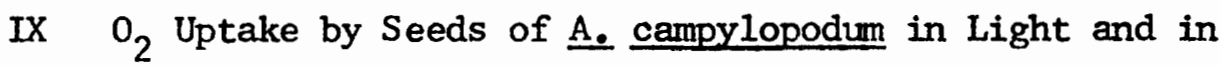

Dark Measured by Polarographic Methods . . . . 33

$\mathrm{X}$ Distribution of ${ }^{14} \mathrm{C}$ in Seeds of A. campylopodum .... 35

XI Separation of Water-Soluble ${ }^{14} \mathrm{C}$ Components by Ion

Exchange Chromatography .......... 36

XII Comparison of Germination Rates Between Years by

Pretreatment ............. 4 44 
XIII Comparison of Germination Rates from Pretreatments of Seeds with Three Solutions (1\%, 2\%, and $3 \%$ ) of $\mathrm{H}_{2} \mathrm{O}_{2}$ by Year ......................

XIV Anova Table Germination Rates of Seeds of A. campy10podum Pretreated with Various Solutions of Chlorox

XV Anova Table Chlorophyll Concentrations in Aerial Shoots and Seeds of Four Species of Dwarf Mistletoe ...

XVI Anova Table $\mathrm{O}_{2}$ Uptake by Seeds of $\mathrm{A}_{\text {. campylopodum }}$ Measured by Manometric Methods . . . . . . 48 XVII Anova Table $\mathrm{O}_{2}$ Uptake by Seeds of $\underline{A}$. campylopodum Measured by Polarographic Methods . . . . . . . 


\section{LIST OF FIGURES}

FIGURE

PAGE

1. Flow Chart for ${ }^{14} \mathrm{C}$ Label Proceedure and Analysis . . . 17

2. Annual Mean Germination Percentages for A. campylopodum

Pretreated with Various Strength Solutions of $\mathrm{H}_{2} \mathrm{O}_{2}$ - 20

3. $\mathrm{O}_{2}$ Uptake in Lignt and in Dark by Seeds of

A. campylopodum . . . . . . . . . . . 32 


\section{INPRODUCTION}

Dwarf mistletoes (Arceuthobium sp.) are parasitic angiosperms which grow upon members of the Pinaceae in North America. They adversly affect their hosts in a variety of ways: by reducing tree growth, by distorting normal patterns of growth, by reducing seed yield, by reducing resistance to other diseases and insects, and in severe cases by causing death (Beckman, 1964; Hull and Leonard, 1964). Childs and Shee (1967) estimate the ammual loss of wood in Oregon and Washington due to dwarf mistletoe to be $147 \times 10^{6}$ cubic feet. The infection process begins when the radicle of a germinating seed forms a holdfast. The holdfast develops a wedge-like piece of tissue which then penetrates the host (Hawksworth and Wiens, 1972). Knowledge of dwarf mistletoe seed physiology is important to the establishment of effective methods of control of the parasite.

While the primary purpose of this investigation was to examine the photosynthetic capacity of dwarf mistletoe seeds, other physiological characteristics of the seeds were studied. Since it was necessary to germinate substantial quantities of seeds, germination data was accumulated. Owing to fungal contamination of germinating seeds several experiments were designed to test the effectiveness of various delutions of $\mathrm{H}_{2} \mathrm{O}_{2}$ and Chlorox as anti-fungal pretreatment solutions. Chlorophy1l concentrations were determined for seeds and aerial shoots of four species of Arceuthobium. Net $\mathrm{O}_{2}$ incorporation by seeds of $\mathrm{A}$. campylopodum in light and dark was measured by manometric and polaro- 
graphic methods. Experiments were carried out to determine the extent of assimilation of ${ }^{14} \mathrm{CO}_{2}$ in the light and in the dark. 


\section{LITERATURE REVIEW}

\section{GERMINATION}

Beckman and Roth (1968) and Knutson (1974) have defined germination as the stage when the radicles have emerged from the endocarps of the seeds. In vitro germination of dwarf mistletoe seeds is dependent on various factors including a dormancy or an after ripening period, storage conditions, length of storage, and environmental conditions such as presence or absence of light, light intensity, moisture, presence of pathogens (fungi and bacteria), and temperature (Becknan, 1964; Scharpf, 1970; Knutson, 1974; and Wicker, 1974).

Water is the most important requirement for germination (Kuijt, 1969)。 While light is not presently considered to be an absolute requirement for germination, both Scharpf and Parmeter (1962) and Beckman (1964) reported that light significantly increased the percentage of seeds which germinated. Beckman (1964) reported germination rates over $70 \%$ for seeds exposed to light at 680 foot candles as compared with rates of $35 \%$ for seeds germinated in the dark.

Various germination rates for different species under light have been reported. Bonga (1965) reported $75 \%$ germination in seeds of A. pusillum which had been surface sterilized with $3 \% \mathrm{H}_{2} \mathrm{O}_{2}$. He found that $\mathrm{NaOCl}, \mathrm{MgCl}_{2}$, and ethanol were unsatisfactory as surface sterilizers. Beckman and Roth (1968) examined the effect of various constant temperatures during storage upon germination of A. campylo- 
podum. They appeared to have a short dormancy as only $2 \%$ of seeds stored for 30 days at $1.5^{\circ} \mathrm{C}$ germinated while $80 \%$ of seeds stored for 180 days at $1.5^{\circ} \mathrm{C}$ germinated. Knutson (1974) reported an apparent dormancy period for A. campylopodum in the germination rates were low (10-20\%) immediately after harvest but increased to a maximu of $70-$ $80 \%$ in seeds stored for $80-100$ days. Germination dropped to $10-20 \%$ after 450 days. Wicker (1974) reported germination rates resulting from several different treatments of several species. In seeds stored 30-165 days at $5^{\circ} \mathrm{C}$ he reported the following rates: A. abietenum, 77\%; A. americanum, 78\%; A. campylopodum, 85\%; A. douglasii, 56\%; and A. tsugense, $68 \%$. He also tested for dormancy and reported that germin-

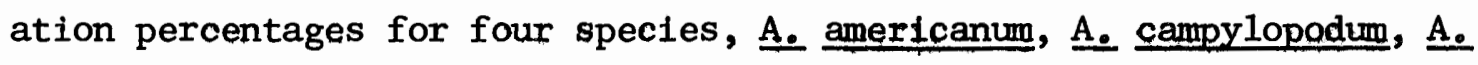
laricis, and A. douglasii, increased from $0 \%$ at dispersal time to 55$85 \%$ at two weeks post-dispersal. The rates leveled off during the next three weeks to yield maximum rates of $80-90 \%$ except for $\underline{\text {. }}$ laricis, which had maximum rates between 50 and $60 \%$. This one to two week dormancy is much shorter than those reported earlier (Beckman and Roth, 1968, and Knutson, 1974) of 30-60 days for seeds of A. campylopodum.

\section{PHOTOSYNTHESIS}

Most of the previous investigations concerning photosynthesis in dwarf mistletoe have been on the aerial shoots' ability to assimilate $\mathrm{CO}_{2}$. Rediske and Shea (1961), studying photosynthesis in A. americanum growing on Pinus contorta, found that the aerial shoot assimilated $\mathrm{CO}_{2}$ and also accumulated photosynthate, mainly sucrose, from the 
host. They proposed that the dwarf mistletoe acted as a physiological girdle, intercepting all photosynthate produced distal to the infection site, blocking its basipetal translocation. Hull and Leonard

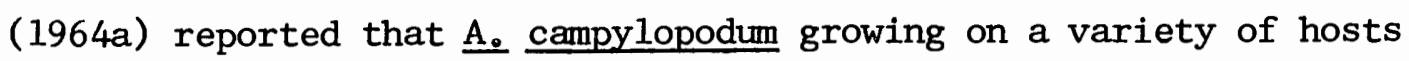
also assimilated $\mathrm{CO}_{2}$. They also reported that dwarf mistletoe accumulated photosynthate, principally sucrose from the host throughout the year, and found that basipetal translocation of photosynthate in the host's branches was not blocked by dwarf mistletoe infections. Hull and Leonard (1964b) found the parasite photosynthate was never translocated to the endophytic system or to the host. They reported chlorophy11 concentrations in dwarf mistletoes from 0.24 to $0.48 \mathrm{mg} / \mathrm{g}$ dry weight, 10 to $20 \%$ of that found in the hosts. Miller and Tocher (1975) found that aerial shoots of A. tsugensi f1xed $10-15 \%$ of available ${ }^{14} \mathrm{CO}_{2}$ in one hour. Their IRGA studies showed an apparent $\mathrm{CO}_{2}$ fixation rate of $80-90 \mu \mathrm{CO}_{2} \mathrm{~g}^{-1} \mathrm{~h}^{-1}, 20-30 \%$ of the amount of $\mathrm{CO}_{2}$ produced during respiration.

Tainter (1971) reported that chloroplasts in A. pusillum contained no distinct grana, but a variable number of parallel lamellae. The chloroplasts accumulated large amounts of starch and were functional. Chloroplasts were found in the aerial shoots, the endophytic system, and in the endosperm of seeds. However, Dodge and Lawes (1974) describe the chloroplasts of A. oxycedri to be large, consisting of numerous grana made up of varied number of thylakoids and extensive lamellae. The stroma contains DNA, occasional starch grains and ribosomes. These chloroplasts are typical angiosperm chloroplasts. It appears that the chloroplasts show variation between 
species and more investigation is needed.

There have been several observations that dwarf mistletoe seeds contain chlorophyll and this has resulted in speculation that the seeds have photosynthetic capability. Cohen (1963), in a description of the anatomy of the seedling, described the stomates, attributing them with the function of gas exchange during "probable photosynthesis in the green, long-lived seedlings." Kuijt (1969) referred to the chlorophyllous endosperms of the Viscaceae as "seats of great photosynthetic activity." Scharpf (1970) commented on the possibility that photosynthesis occurs in the chlorophyllous seeds, supplying energy necessary for establishment on the host. Muir (1975) did two experiments in which he exposed ten germinated seeds each to ${ }^{14} \mathrm{CO}_{2}$ in $\mathrm{light}$ and in dark. He reported that the seeds exposed for 48 hours in light averaged 2,440 cpm and in dark averaged $310 \mathrm{cpm}$. He concluded that although the amount of $\mathrm{CO}_{2}$ assimilated was small, it may play a significant role in the supply of energy to the seeds. 


\section{MATERIALS AND METHODS}

\section{COLLECTION AND STORAGE OF SEEDS}

Seeds were collected during September and October of 1975, 1976, and 1977 (see Table I for dates and sites). Seeds were collected by placing a brown kraft bag over aerial shoots with ripe fruits and shaking vigorously. This shaking induced the seeds to fire and stick to the bag. In some cases aerial shoots were picked from the host tree, placed in a bag and shaken vigorously with the seeds firing and sticking to the bag. Once a bag was full, it was placed in an ice chest until arrival at the laboratory. In the laboratory seeds were removed from the bags by soaking them in warm water thereby hydrating the viscin permitting the seeds to slide free. They were then rinsed several times to remove dirt and debris. When the seeds appeared to be reasonably clean, they were spread onto $9 \mathrm{~cm}$ filter papers and allowed to dry. The storage proceedure was slightly modified from Knutson (1974) in that the filter paper discs were strung on a string with approximately $0.5 \mathrm{~cm}$ between each disc, instead of being placed on a glass rod. The string was affixed to a lid of a gallon jar and suspended in the jar over a saturated $\mathrm{NaCl}$ solution. The lids were sealed and the jars were stored in a refrigerator at approximately $4^{\circ} \mathrm{C}$. This method results in a relative humidity of $75 \%$ inside the storage jar (Knutson, 1971). 


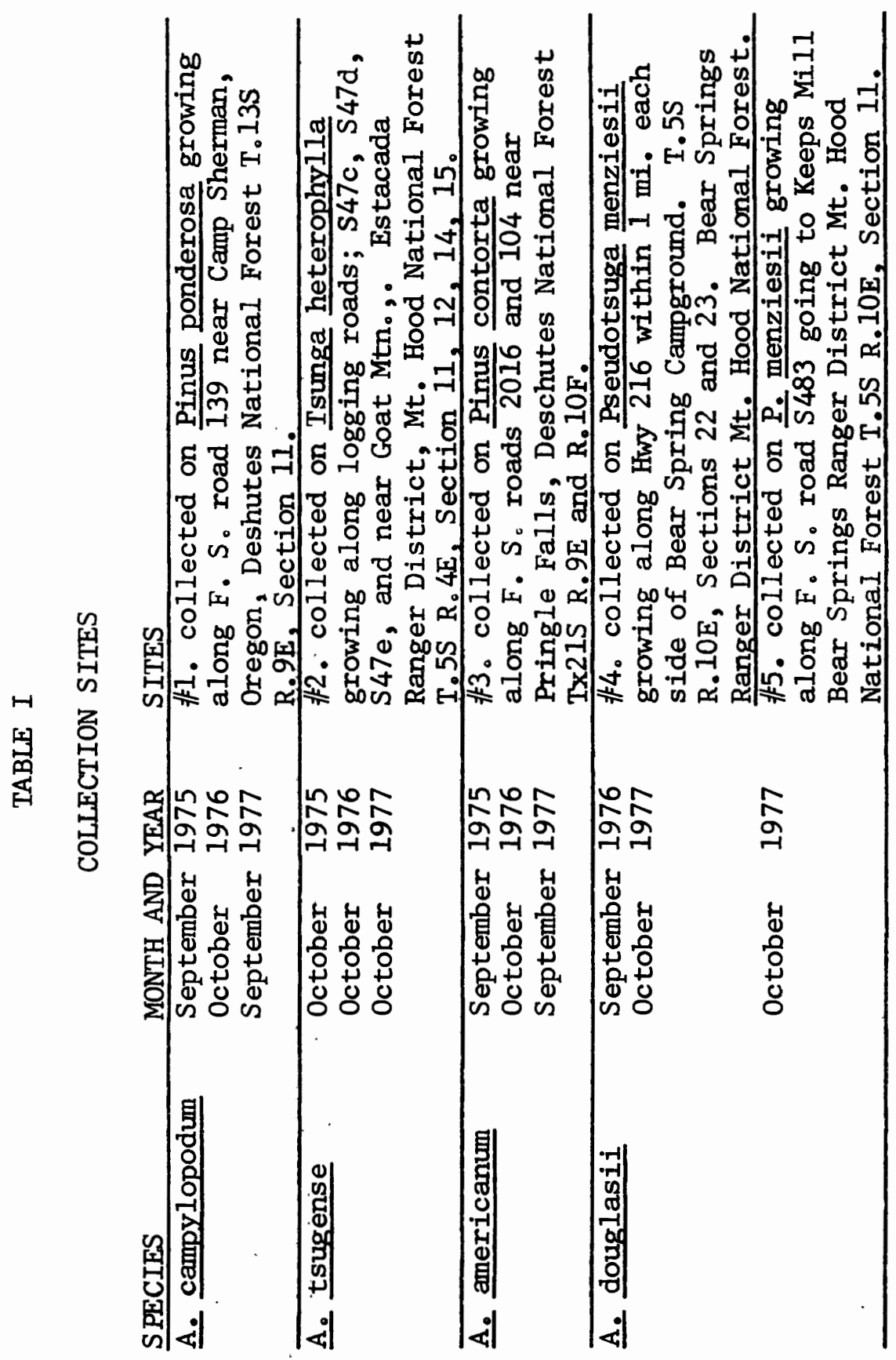




\section{GERMINATION OF SEEDS}

Seeds of Arceuthobium campylopodum were used in the following germination studies. The general method used for germinating the seeds in most of the physiological experiments in this study was as follows. The seeds were first removed from filter papers by soaking in water for an hour, then they were soaked in $2 \% \mathrm{H}_{2} \mathrm{O}_{2}$ for one hour to surface sterilize. Then they were rinsed three times with sterile distilled $\mathrm{H}_{2} \mathrm{O}$ and transferred to a clean beaker and covered with sterile distilled $\mathrm{H}_{2} \mathrm{O}$. The water was changed daily to further discourage growth of microorganisms. When seeds germinated (the radicles ruptured the endocarp crests) they were separated from nongerminated seeds and placed in petri dishes. These seeds were watered once a day and any excess water was poured off. The seeds were kept in either a light box in a refrigerator or in an environmental growth chamber. Temperature ranged from 4 to $15^{\circ} \mathrm{C}$. Light intensity was measured in the growth box at $4.3 \times 10^{3}-5.4 \times 10^{3}$ lux and in the growth chamber between $1.08 \times 10^{4}-1.40 \times 10^{4}$ lux.

The effects of different concentrations of $\mathrm{H}_{2} \mathrm{O}_{2}$ on seed germination and inhibition of fungal growth on seeds were tested using a series of solutions of 1,2 , and $3 \% \mathrm{H}_{2} \mathrm{O}_{2}$. Seeds were placed in petri dishes at the rate of 100 per dish. They were then soaked in one of the solutions (four dishes/solution) for one hour, then rinsed three times with sterile distilled $\mathrm{H}_{2} \mathrm{O}$, and finally covered with sterile $\mathrm{H}_{2} \mathrm{O}$. Water was changed daily to further prevent contamination by microorganisms. Records of number of seeds germinated per plate were 
kept. This experiment was run each year, 1975, 1976, and 1977, to see if germination rates showed annual variations. The second and third year five instead of four samples were used for each treatment. During December 1976 a similar experiment was made, testing the effects of pretreatment of various strength (one to five percent) solutions of Chlorox on seed germination and fungal contamination. Fifteen samples of fifty seeds each were used, three samples per treatment. The seeds were placed in petri dishes and soaked in either $1,2,3,4$, or $5 \%$ solutions of Chlorox for one hour. Then the seeds were rinsed three times with sterile distilled $\mathrm{H}_{2} \mathrm{O}$ and then were covered with sterile distilled water, which was changed daily. Percentages of germination were recorded.

In January 1978 an experiment was carried out to determine if a short exposure (five minutes) to red light enhanced germination of A. campylopodum seeds. Two 100 seed samples in petri dishes (uncovered) were placed in a box with a red light filter $(650 \mathrm{~nm})$ taped over the top. Light was provided by a 150 watt light in a goose neck lamp. Light intensity was measured at $3.2 \times 10^{3}$ Iux using a General Electric type X23 light meter. The box was placed in a refrigerator during the five minute exposure time to avoid excessive heating. A control of 130 seeds was used. After the exposure seeds were soaked for one hour in $2 \% \mathrm{H}_{2} \mathrm{O}_{2}$, rinsed with sterile distilled $\mathrm{H}_{2} \mathrm{O}$, and were covered with sterile distilled $\mathrm{H}_{2} \mathrm{O}$. The control was similarly treated with $2 \% \mathrm{H}_{2} \mathrm{O}$ and soaked in sterile water. The water was changed daily。 Germination records were kept for a thirty day period. 
DETERMINATION OF CHLOROPHYLL CONCENTRATIONS IN SEEDS

AND AERIAL SHOOTS OF FOUR SPECIES OF DWARF MISTLETOE

Chlorophy11 concentrations were determined for seeds and aerial shoots of four species of Arceuthobium: A. campylopodum, A. tsugense, $\underline{A_{0}}$ americanum, and $\underline{A_{0}}$ douglasii.

A preweighed amount $(0.500 \mathrm{~g})$ of each species of seeds was used for each determination. A Sorval Micromixer was used to grind the seeds, Since the volume of the grinder container was limited, it took two or three grinding perfods to grind $0.500 \mathrm{~g}$ of seeds. Part of the seeds were placed in the grinding container with a small volume (approximately $10.0 \mathrm{ml}$ ) $80 \%$ acetone. The container was attached to the mixer and the seeds were ground for fifteen minutes. The container was partially submerged in a cold water bath during grinding to prevent excessive heating. The extract was filtered three times through Whatman $\|_{1} 1$ filter discs on a Buchner funnel into a foil wrapped side-arm flask. The extract was diluted to known volume. A known volume of extract was placed in a cuvette and the absorbance was measured in a Coleman 124 Spectrophotometer. This sample was concentrated under $\mathrm{N}_{2}$ or diluted with additional $80 \%$ acetone to give an absorbance reading between 0.60 and 1.00 at $663 \mathrm{~nm}$. Then a spectrum was obtained between $700 \mathrm{~nm}$ and $400 \mathrm{~nm}$.

The formulas that were used to estimate the chlorophyll content are those reported in Holden (1965):

$$
\text { Chlorophyll } a=\frac{0.0127(\mathrm{~A} 663)-0.00269(\mathrm{~A} 645) \mathrm{X} \text { vol. of extract (ml) }}{\text { fresh weight material }(\mathrm{g})}
$$


Chlorophyl1 $b=\frac{00.0229(\mathrm{~A} 645)-0.00468(\mathrm{~A} 663) \times \text { vol。of extract(m1) }}{\text { fresh weight material }(\mathrm{g})}$

The method used for determining aerial shoot chlorophyll

concentrations was basically the same as the above proceedure with the following exceptions. Freeze-dried aerial shoot tissue $(5.0 \mathrm{~g})$ was homogenized with $75-100 \mathrm{ml} 80 \%$ acetone in a Sorval Omnimixer without the micromixer attachment. Chlorophyll determinations for seeds and shoots were repeated three times for each species.

MANOMETRIC DETERMINATIONS OF $\mathrm{O}_{2}$ UPTAKE

Rates of $\mathrm{O}_{2}$ uptake in light and dark by dwarf mistletoe seeds were measured by manometric methods. A Gilson Medical Electronics Warburg Constant Volume Respirometer was used in these experiments in conjunction with a Neslab Constant Temperature Circulation Bath, which holds a constant temperature $\left(25^{\circ} \mathrm{C}\right)$ even during periods of illumination. Light intensity was approximately $8.6 \times 10^{4}$ lux. Double sidearm Warburg flasks $(21.0 \mathrm{ml})$ were used as reaction vessels. The seeds (ten, preweighed) were placed in the main compartment. Pardee buffer $(0.9 \mathrm{ml})$ was placed in one of the sidearms along with a folded filter paper wick to maintain the $\mathrm{CO}_{2}$ concentration inside the flask at one percent (Umbreit, et al. 1959). Sterile distilled water $(1.1 \mathrm{ml})$ was put into the other sidearm to maintain a humid environment. Flasks used to measure dark $0_{2}$ uptake were wrapped in aluminum foil. All glass to glass connections were sealed with Lubriseal. The flasks were then commected to the manometers and placed in the lighted $25^{\circ} \mathrm{C}$ water bath. After a fifteen minute equilibration period the 
manometer stop cocks were closed and the experiment started. Two thermobarometers were used with each experiment. Each contained 0.9 $\mathrm{ml}$ Pardee buffer in one sidearm and $1.1 \mathrm{ml}$ sterile distilled $\mathrm{H}_{2} \mathrm{O}$ in the other sidearm. Manometer readings were taken and recorded every fifteen minutes for the four hour duration. Flask constants $\left(\mathrm{K}_{\mathrm{O}_{2}}\right)$ were computed for the flasks with two ml fluid volume and for $25^{\circ} \mathrm{C}$ using the formula from Umbreit, et al. (1959). The amount of gas exchanged equaled the change in manometer reading $(h)$ times the flask constant $\left(\mathrm{K}_{2}\right)$.

POLAROGRAPHIC DETERMINATION OF $\mathrm{O}_{2}$ UPTAKE

A Yellow Springs Instrument Mode1 53 Biological Oxygen Monitor and a Sargent Recorder were used to measure and record $\mathrm{O}_{2}$ uptake in light and dark by A. campylopodum seeds. Temperature was kept constant by using the Neslab Constant Temperature Circulation Water Bath. Illumination was provided by a 150 watt soft white bulb in a goose neck lamp。 Light intensity was $1.29 \times 10^{4}$ lux。 During dark runs the reaction chamber was covered with a dark blue cloth and the light source turned off. The machine was calibrated as described in the instruction manual (Y.S.I. Co。1969) using $\mathrm{O}_{2}$ saturated distilled $\mathrm{H}_{2} \mathrm{O}$ at $25^{\circ} \mathrm{C}$ 。 A probe test was run daily and the membrane was changed whenever necessary to insure reliability. Special stirring discs with flat surfaces were used because the regular type stirrer discs tended to mascerate the seeds.

Five seeds (preweighed) were put into the reaction chamber containing $3.0 \mathrm{ml} \mathrm{O}_{2}$ saturated water. The probe was inserted and the 
stirrer was turned on. After a five minute equilibration period was over, the light source was turned off and the reaction vessel was covered with the dark cloth. $\mathrm{O}_{2}$ uptake measurements were taken during alternating fifteen minute dark and light periods.

$$
\text { INCORPORATION OF }{ }^{14} \mathrm{CO}_{2}
$$

Three samples of seeds (70-100, preweighed) in three reaction flasks were exposed to ${ }^{14} \mathrm{CO}_{2}$ for twenty-four hours (see Figure 1)。 Each reaction flask consisted of two parts: a glass vial and a $25 \mathrm{ml}$ suction flask. A piece of rubber tubing (approximately $2.0 \mathrm{~cm}$ long) was fitted on the sidearm of each suction flask to provide a seal to which the vial was attached. The seeds were placed in the vials and then the vials were fitted on the rubber covered sidearms. The rubber to glass joints were sealed with silicone grease. The tops of the suction flasks were fitted with serum stoppers. A Kontes cup, a small plastic cup (volume $0.4 \mathrm{ml}$ ) on a plastic stem $(6.0 \mathrm{~cm}$ ), was suspended from a serum stopper (through which a hole was drilled to hold the stem of the plastic cup) into each reaction flask. Each plastic Kontes cup contained $0.15 \mathrm{ml}$ of $0.2 \mathrm{~N} \mathrm{NaH}^{14} \mathrm{CO}_{3}$, equivalent to $1.5 \times 10^{6}$ dpm per flask. ${ }^{14} \mathrm{CO}_{2}$ was liberated in each flask by injection $0.15 \mathrm{~m} 1$ of $2 \mathrm{~N} \mathrm{H}_{2} \mathrm{SO}_{4}$ to the $\mathrm{NaH}^{14} \mathrm{CO}_{3}$. One flask was foil wrapped to determine if $\mathrm{CO}_{2}$ assimilation occured in the dark. The flasks were then suspended in the Warburg water bath. Temperature was kept constant at $25^{\circ} \mathrm{C}$ using the Neslab portable bath.cooler. Light intensity was $8.6 \times 10^{4}$ lux. 
After twenty-four hours, $5.0 \mathrm{ml}$ of ten percent KOH was injected into the bottom of each reaction flask. The flask was then shaken for two hours. The sidearm vial containing the seeds was then removed, filled with hot $95 \%$ ethanol and capped. Aliquots of $\mathrm{KOH}$ were counted for ${ }^{14} \mathrm{C}$ activity using a Nuclear Chicago Unilux II Liquid Scintillation Counter to determine the amount of ${ }^{14} \mathrm{CO}_{2}$ remaining in the reaction flask. Each aliquot was added to a counting vial containing ten $\mathrm{ml}$ of scintillation fluid (12 $\mathrm{g}$ PPO, $330 \mathrm{mg}$ POPOP, in a tolueneabsolute ethanol solution $2: 1 \mathrm{v} / \mathrm{v}$ ). Efficiency was determined by Channe1s Ratio method (Wang and Willis, 1965). The seeds in hot ethanol were transferred to a blender container, connected to a Sorval Omnimixer, and ground for fifteen minutes. The extract and residue were filtered twice using preweighed filter papers on a Bucher funnel and the residue dried. The volume of the ethanol soluble fraction was measured, and aliquots counted for ${ }^{14} \mathrm{C}$ activity. The dried residues were weighed and samples were combusted in Schoninger Oxygen Flasks with $2.0 \mathrm{ml}$ ten percent $\mathrm{KOH}$ in the bottom. Aliquots of the $\mathrm{KOH}$ were assayed for ${ }^{14} \mathrm{C}$ activity.

Next, the ethanol soluble fraction was evaporated under partial vacurm at $35^{\circ} \mathrm{C}$ to dryness in a round bottom flask. The concentrate was partitioned between water and chloroform and then transferred to a separatory funnel where the phases were separated. The volume of each phase was measured. The ${ }^{14} \mathrm{C}$ activity was assayed to determine the percentage of photosynthate incorporated in chloroform and water soluble fractions.

Ion exchange chromatography was used to separate the water 
soluble fractions, using colums prepared according to instructions in Wharton and McCarty (1972). The fraction was first passed through a cation exchange colum (Amberlite IRC-50, $\mathrm{Na}^{+}$form) and then through an anion exchange column (Dowex 2- $\mathrm{X} 8, \mathrm{OH}^{-}$form). Aliquots of the effluents were assayed for ${ }^{14} \mathrm{C}$ activity to determine the percentage of activity remaining on the columns. The columns were eluted with $2 \mathrm{~N} \mathrm{NaOH}$. Aliquots of the elution were also counted. 


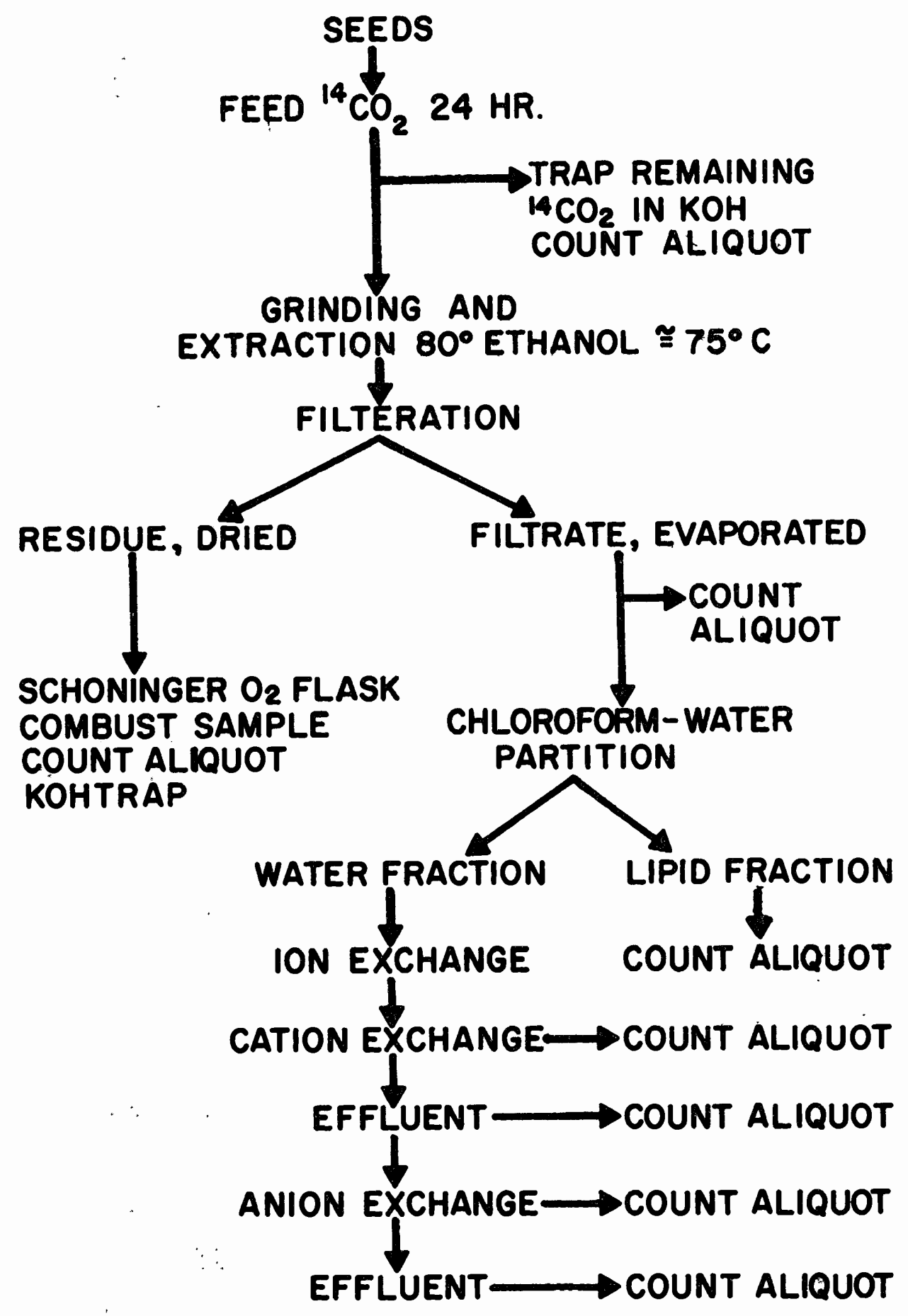

Figure 1. Flow chart for ${ }^{14} \mathrm{C}$ Label Procedure and analysis 


\section{RESULTS AND DISCUSSION}

\section{GERMINATION}

Germination percentages from the experiments on the effect of $\mathrm{H}_{2} \mathrm{O}_{2}$ on seed germination are compiled in Table II and in Figure 2. Statistical treatment included one way analysis of variance (ANOVA) between treatments in a fiven year and for similar treatments between years. If the ANOVA's showed significant differences, the StudentNewman-Keuls (SNK) test was utilized to determine where specific differences between means existed. The results of the statistical analysis are summarized in Table III. In all three years there was no significant difference between the two percent and three percent $\mathrm{H}_{2} \mathrm{O}_{2}$ treatments for the respective year. In 1975 the one percent $\mathrm{H}_{2} \mathrm{O}_{2}$ treated seeds had significantly lower germination percentages than did the two percent and three percent treated seeds, but in 1976 and in 1977 the three pretreatments resulted in no significant difference in terms of percentage of seeds germinated. Comparison between the years showed that 1976 seeds had higher rates of germination than 1975 and 1977 seeds similarly treated. The 1975 seeds in the two percent and three percent treatments had significantly higher germinations than those of 1977, while the one percent treatments resulted in similar germination rates.

Fungal contamination of incubating seeds was a continous problem. Seeds treated with only sterile distilled $\mathrm{H}_{2} \mathrm{O}$ were almost certain to 
TABLE II

CERMINATION PERCENTAGES FOR SEEDS

OF A. CAMPYLOPODUM TREATED

WITH $\mathrm{H}_{2} \mathrm{O}$

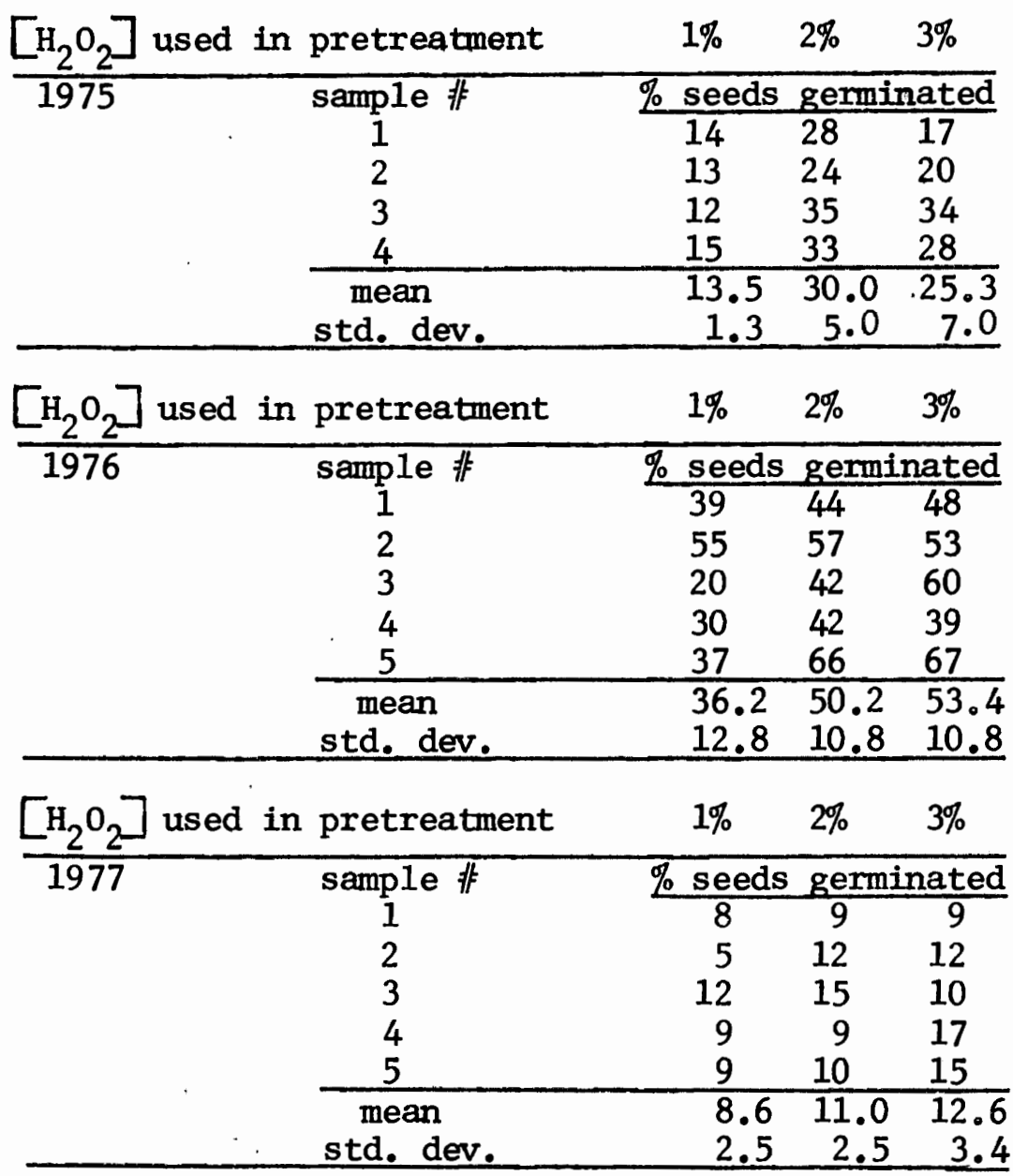




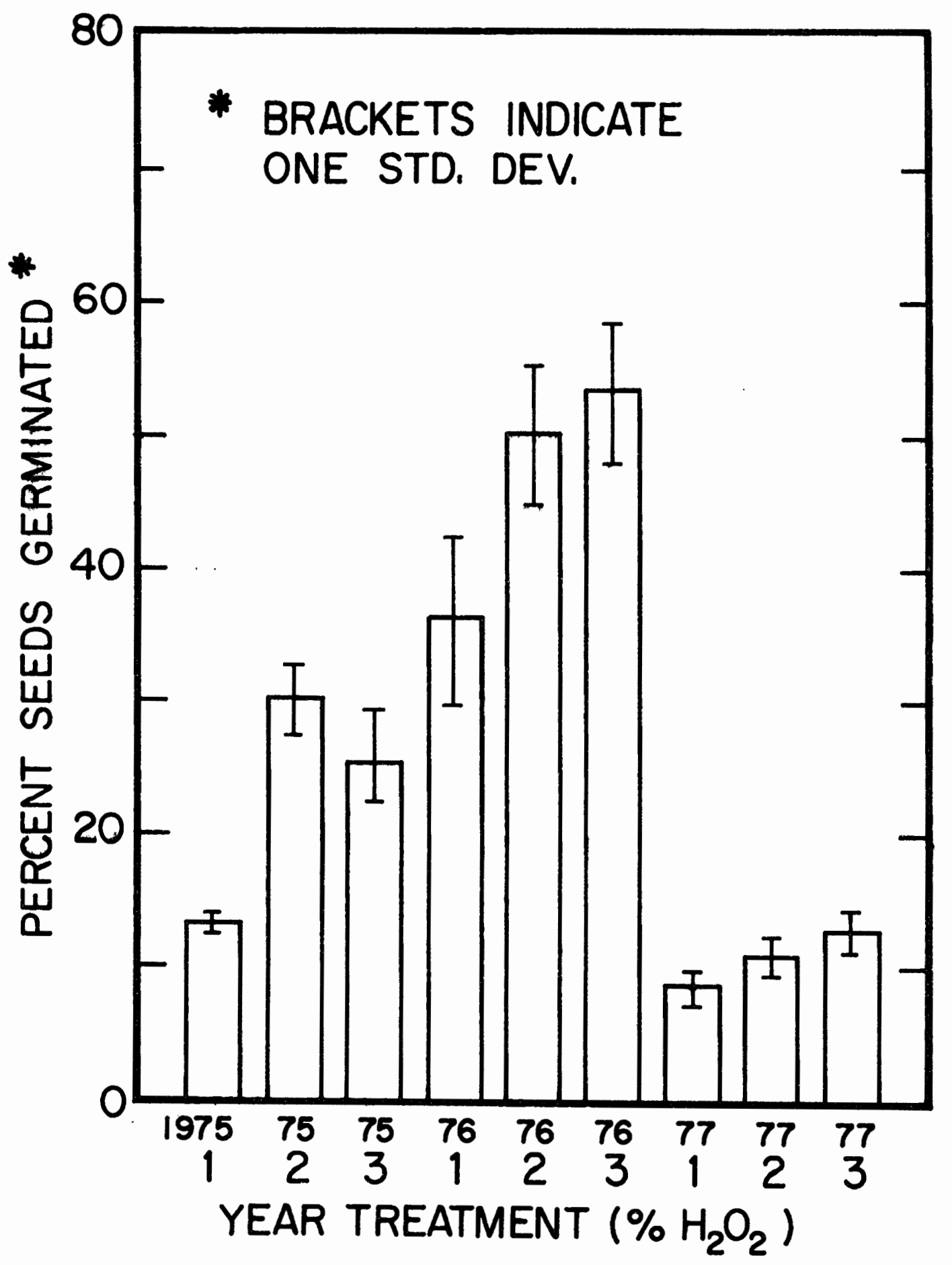

Figure 2. Annual mean germination percentages for A. campylopodum seeds pretreated with various strength solutions of $\mathrm{H}_{2} \mathrm{O}_{2}$ 


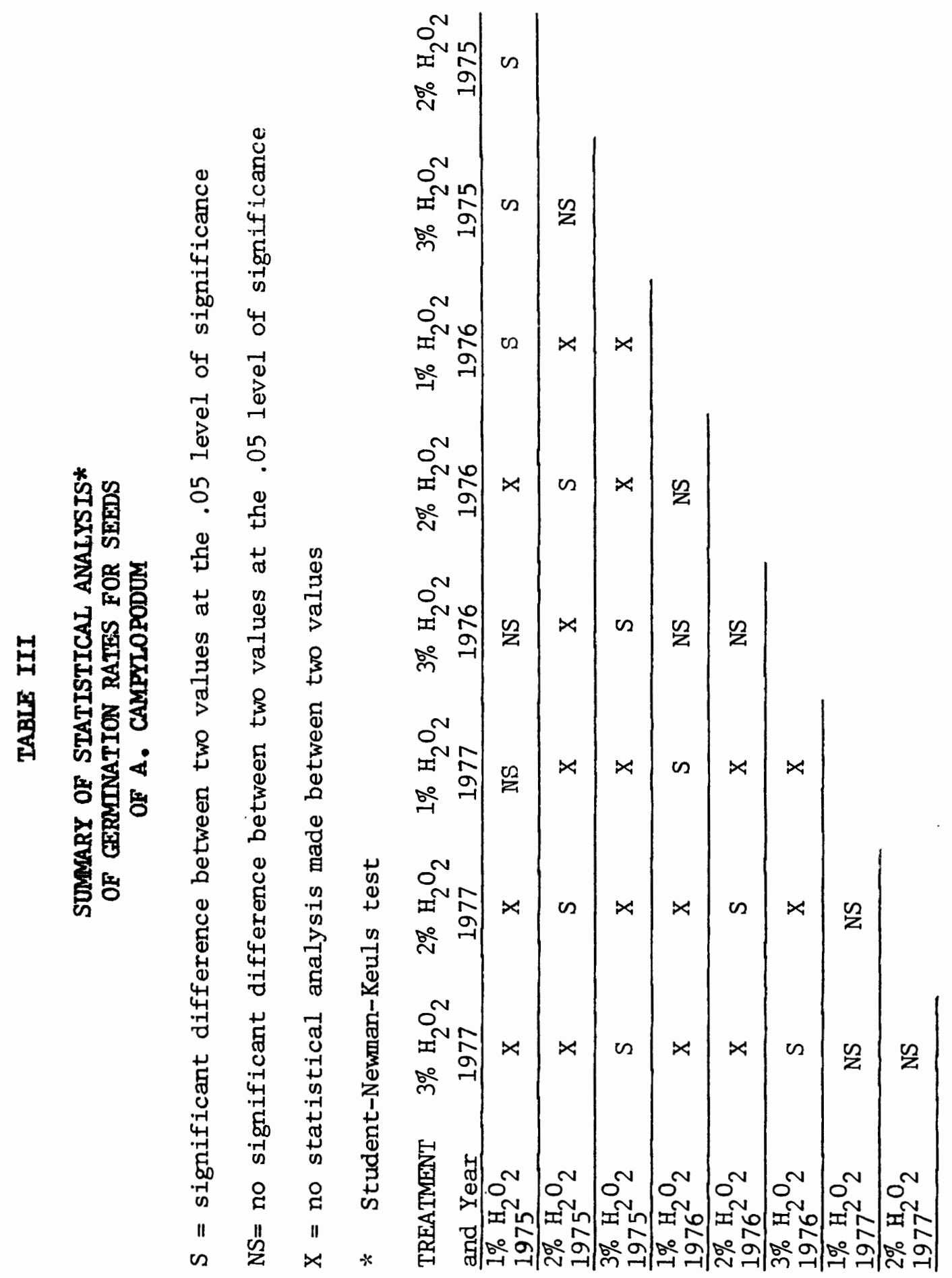


be overcome with fungi. It was most severe in the 1975 seeds. This is one of the possible explanations for the difference in germination rates between 1975 seeds and 1976 seeds. However, even in the absence of fungal contamination, and with similar treatment, seeds which appeared normal (green and non-shrivelled, Wicker, 1974) often did not germinate. This tendency was most apparent in the 1977 seeds where germination rates were quite low. Many of these seeds appeared to be normal but within a week after imbibition turned yellow. These seeds were separated from the green, healthy seeds but soon became heavily contaminated by fungi. It should be noted that 1977 was a year of severe drought in Oregon and, although any comection would be speculation at this point, a study of the effect of drought on fruit development in Arceuthobium would be worth while.

The maximum germination rate of $67 \%$ for A. campylopodum obtained in this study is roughly comparable to those of Knutson (1974) but somewhat smaller than those reported by Beckman (1964) and Wicker (1974). Wicker (1974) preselected against abnormal seeds in collections, and this fact may explain the $85-90 \%$ germination rates he reported. However, it can easily be seen from my data that germination rates are quite variable within the species from year to year and quite likely, from site to site.

The data from tests using dilutions of Chlorox as anti-fungal agents is in Table V. Pretreatment with Chlorox dilutions yielded low germination rates, six to twenty percent (means), as compared to fifty percent (mean) for a control using $\mathrm{H}_{2} \mathrm{O}_{2}$ (two percent). The treatment with Chlorox tended to cause many of the seeds to turn yellow within 
TABLE IV

\section{GERMINATION OF SEEDS OF A. CAMPYLOPODUM PRETREATED WITH CHLOROX}

\begin{tabular}{|c|c|c|c|c|c|c|}
\hline $\begin{array}{r}\text { Pret: } \\
\text { So } \\
{[\mathrm{C}]}\end{array}$ & $\begin{array}{l}\text { eatment } \\
\text { lution } \\
\text { llorox] }\end{array}$ & $1 \%$ & $2 \%$ & $3 \%$ & $4 \%$ & $5 \%$ \\
\hline 1976 & sample 非 & Perce & tages & Seeds & Germ & inatec \\
\hline & 1 & 36 & 16 & 16 & 6 & 9 \\
\hline & 2 & 18 & 10 & 13 & 10 & 6 \\
\hline & 3 & 6 & 20 & 6 & 9 & 5 \\
\hline & mean & 20 & 15 & 11.7 & 8.3 & 6.7 \\
\hline & std. dev & 15 & 5.0 & 5.1 & 2.0 & 2.0 \\
\hline
\end{tabular}

Control pretreated with $3 \% \mathrm{H}_{2} \mathrm{O}_{2}$

\begin{tabular}{cc}
\hline sample $\equiv_{1}$ & $\begin{array}{c}\% \text { seeds } \\
\text { germinated }\end{array}$ \\
\hline 1 & 50 \\
2 & 60 \\
3 & 46 \\
\hline mean & 52 \\
std. dev. & 7.2 \\
\hline
\end{tabular}


five days after treatment and this was often followed by fungal infection. Analysis of variance showed no significant difference between the resultant germination rates for the five different treatments. It appears that Chlorox is toxic to many seeds even at the one percent concentration.

Attempts to germinate seeds within thirty days after dispersal proved futile, but by forty $f$ flve to sixty days post dispersal, average germination rates were obtainable for seeds of A. campylopodum. This corresponds to apparent dormancy periods reported by Beckman and Roth (1968) and Knutson (1974). However, Wicker (1974) reported maximum germination rates were obtained within two weeks after dispersal. Thus there is controversy over the length of the dormancy expressed in seeds of A. $_{\text {campylopodum. }}$

Presently it is thought that under natural conditions germination takes place in early to late spring (Hawksworth and Weins, 1972)。 Beckman (1968) reported that some seeds stored in the field germinated in February. He proposed that a prolonged cold period is required which caused the degradation of a hypothetical chemical inhibitor in the seed allowing germination. He also reported germination over wide ranges of temperature $\left(5-30^{\circ} \mathrm{C}\right)$. Light, temperature, and moisture are requirements for germination but individually do not appear to be controlling when germination occurs. Beckman (1974) also investigated the effects of red light and far red light on seed germination and found that germination was slightly enhanced by both, red light being slightly more effective than far red light.

My preliminary experiments showed no significant difference 
between a dark control of 130 seeds and two 100 seed samples exposed to red light at $650 \mathrm{~nm}$ for five minutes. It is apparent that our knowledge of factors controlling germination is still inadequate and that further investigation of a germination inhibitor and of other possible controlling factors is needed.

\section{CHLOROPHYLL CONCENTRATIONS}

Chlorophyll concentrations of seeds and aerial shoots are presented in Tables V and VI. One way analysis of variance was used to analyze total chlorophyll concentration. SNK tests were used to determine significant differences between the mean values for seeds and aerial shoots of the four species. Results of these analyses are summarized in Table VII. Seeds of A. douglasii had the highest chlorophy11 concentration of $0.39 \mathrm{mg} / \mathrm{g}$ fresh weight while seeds of A. tsugense had the lowest concentration of $0.25 \mathrm{mg} / \mathrm{g}$ fresh weight. Statistical comparison showed there is no significant difference between chlorophyll concentrations in seeds and aerial shoots of A. douglasii and A. campylopodum while there is significant difference between the total chlorophyll content of seeds and aerial shoots of A. americanum and $\underline{A_{0}}$ tsugense. The ratio of chlorophyll a to chlorophy $11 \mathrm{~b}$ was generally greater in the aerial shoots than in the seeds. These ratios varied from a low of 1.30:1 in seeds of A. tsugense to $2.72: 1$ in aerial shoots of A. douglasii.

Hu1l and Leonard (1964 b) reported substantial variances in aerial shoot chlorophyll content in two species of dwarf mistletoe ranging from 0.24 to $0.48 \mathrm{mg} / \mathrm{g}$ tissue. They reported chlorophyll a to 
TABLE V

\section{SEED CHLOROPHYLL CONCENTRATIONS}

Species

$[\operatorname{ch} 1$ a $] \quad[\operatorname{ch} 1 \quad b] \quad[\operatorname{chl} a+\operatorname{ch} 1 \quad b]$ $\mathrm{mg} / \mathrm{g}$ fr.wt $\mathrm{mg} / \mathrm{g}$ fr.wt $\mathrm{mg} / \mathrm{g}$ fr.wt

\begin{tabular}{|c|c|c|c|c|}
\hline \multirow{5}{*}{ A. campylopodum } & $\mathrm{mg} / \mathrm{g}$ fr.wt & $\mathrm{mg} / \mathrm{g}$ fr.wt & $\mathrm{mg} / \mathrm{g}$ fr.wt & chl $a=$ chl \\
\hline & 0.21 & 0.12 & 0.33 & $1.75: 1$ \\
\hline & 0.19 & 0.15 & 0.34 & $1.27: 1$ \\
\hline & 0.21 & 0.14 & 0.35 & $1.50: 1$ \\
\hline & 0.20 & 0.15 & 0.35 & $1.33: 1$ \\
\hline \multirow{2}{*}{$\begin{array}{c}\text { mean } \\
\text { std. dev. }\end{array}$} & 0.20 & 0.14 & 0.34 & $1.43: 1$ \\
\hline & 0.0095 & 0.0141 & 0.0095 & \\
\hline \multirow[t]{3}{*}{ A. douglasii } & 0.23 & 0.16 & 0.39 & $1.44: 1$ \\
\hline & 0.23 & 0.17 & 0.40 & $1.35: 1$ \\
\hline & 0.22 & 0.17 & 0.39 & $1.29: 1$ \\
\hline \multirow{2}{*}{$\begin{array}{c}\text { mean } \\
\text { std. dev. }\end{array}$} & 0.23 & 0.17 & 0.39 & $1.35: 1$ \\
\hline & 0.0058 & 0.0058 & 0.0058 & \\
\hline \multirow[t]{3}{*}{ A. americanum } & 0.19 & 0.14 & 0.33 & $1.36: 1$ \\
\hline & 0.17 & 0.12 & 0.29 & $1.42: 1$ \\
\hline & 0.19 & 0.13 & 0.32 & $1.46: 1$ \\
\hline \multirow{2}{*}{$\begin{array}{c}\text { mean } \\
\text { std. dev. }\end{array}$} & 0.18 & 0.13 & 0.31 & $1.38: 1$ \\
\hline & 0.0115 & 0.0100 & 0.0208 & \\
\hline \multirow[t]{3}{*}{ A. tsugense } & 0.14 & 0.11 & 0.25 & $1.27: 1$ \\
\hline & 0.14 & 0.11 & 0.25 & $1.27: 1$ \\
\hline & 0.15 & 0.11 & 0.26 & $1.36: 1$ \\
\hline mean & 0.14 & 0.11 & 0.25 & $1.27: 1$ \\
\hline std. dev. & 0.0058 & 0.0000 & 0.0058 & \\
\hline
\end{tabular}


TABLE VI

AERIAL SHOOT CHLOROPHYLL CONCENTRATIONS

\begin{tabular}{|c|c|c|c|c|}
\hline Species & $\begin{array}{l}{\left[\begin{array}{cc}\operatorname{ch} 1 & a\end{array}\right]} \\
\mathrm{mg} / \mathrm{g} \\
\mathrm{fr} . \mathrm{wt}\end{array}$ & 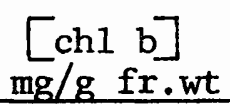 & {$\left[\begin{array}{c}{[\mathrm{ch} 1 \mathrm{a}+\mathrm{ch} 1 \mathrm{~b}} \\
\mathrm{mg} / \mathrm{g} \mathrm{fr} . \mathrm{wt}\end{array}\right]$} & $\begin{array}{l}\text { Ratio } \\
\operatorname{chl} a=\operatorname{chl} b \\
\end{array}$ \\
\hline \multirow{3}{*}{ A. campy lopodum } & 0.21 & 0.15 & 0.37 & $1.40: 1$ \\
\hline & 0.21 & 0.11 & 0.32 & $1.91: 1$ \\
\hline & 0.22 & 0.16 & 0.37 & $1.38: 1$ \\
\hline mean & 0.21 & 0.14 & 0.35 & $1.50: 1$ \\
\hline std. dev. & 0.0057 & 0.0265 & 0.02887 & \\
\hline \multirow{3}{*}{ A. douglasii } & 0.28 & 0.12 & 0.40 & $2.33: 1$ \\
\hline & 0.27 & 0.08 & 0.35 & $3.38: 1$ \\
\hline & 0.28 & 0.10 & 0.38 & $2.80: 1$ \\
\hline \multirow{2}{*}{$\begin{array}{c}\text { mean } \\
\text { std. dev. } \\
\end{array}$} & 0.28 & 0.10 & 0.38 & $2.80: 1$ \\
\hline & 0.0058 & 0.0200 & 0.0252 & \\
\hline \multirow[t]{3}{*}{ A. americanum } & 0.22 & 0.12 & 0.34 & $1.83: 1$ \\
\hline & 0.23 & 0.13 & 0.36 & $1.77: 1$ \\
\hline & 0.23 & 0.11 & 0.35 & $2.09: 1$ \\
\hline \multirow{2}{*}{$\begin{array}{c}\text { mean } \\
\text { std. dev. } \\
\end{array}$} & 0.23 & 0.12 & 0.35 & $1.92: 1$ \\
\hline & 0.0058 & 0.0100 & 0.0100 & \\
\hline \multirow{3}{*}{ A. tsugense } & 0.20 & 0.13 & 0.33 & $1.54: 1$ \\
\hline & 0.20 & 0.09 & 0.29 & $2.22: 1$ \\
\hline & 0.19 & 0.10 & 0.30 & $1.90: 1$ \\
\hline mean & 0.20 & 0.11 & 0.31 & $1.82: 1$ \\
\hline std. dev. & 0.0058 & 0.0208 & 0.0208 & \\
\hline
\end{tabular}




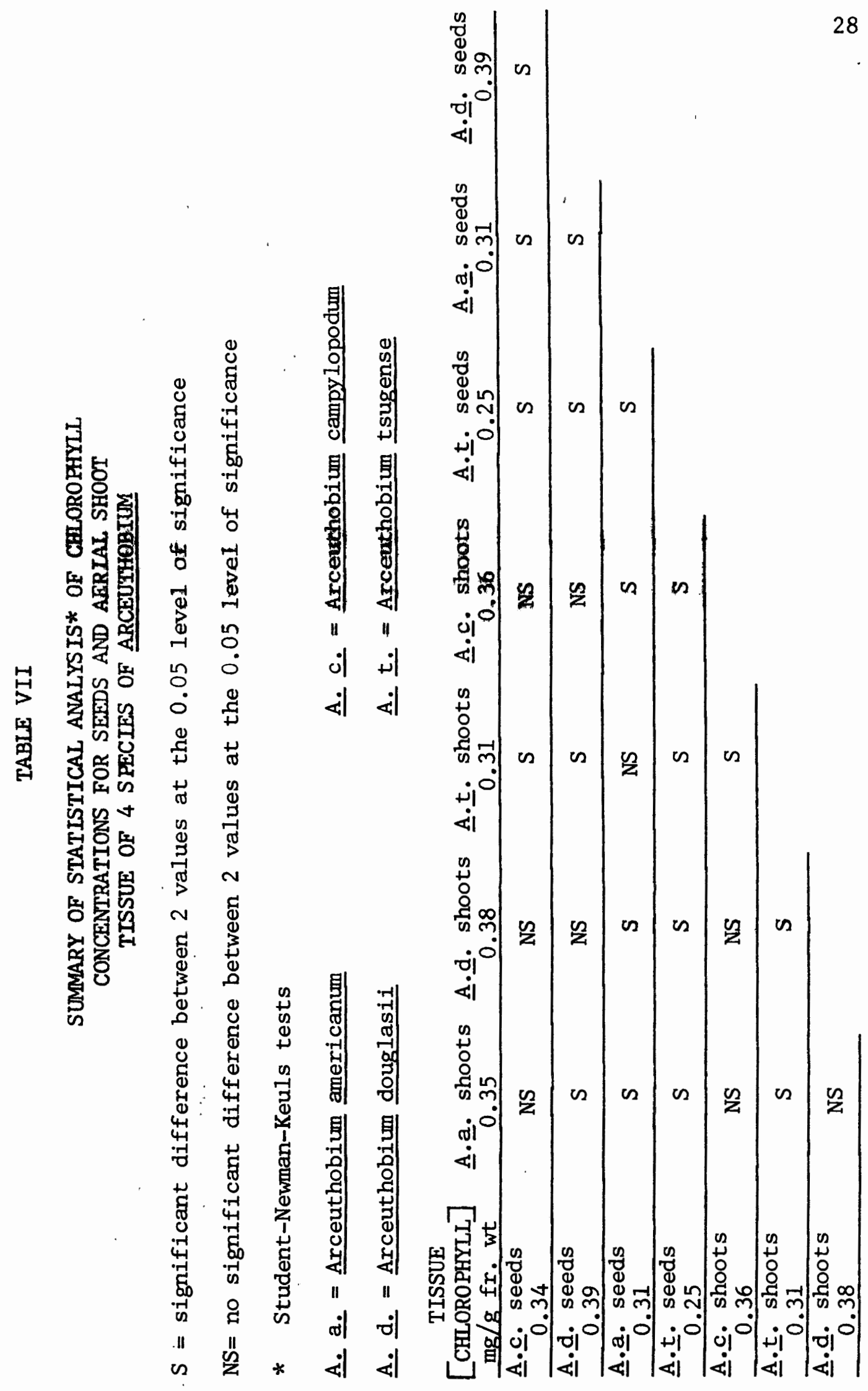


chlorophy11 b ratios in A. campylopodum aerial shoots growing on five different hosts, ranging from 1.9:1 to 3.4:1. However, one should realize they were using Gill's system of classification which previously lumped several presently recognized species into one large species, A. campylopodum. Therefore this seemingly high amount of intraspecific variation of chlorophyll content and ratios of chlorophy11 $a$ to $b$ is in fact interspecific variation.

The biological implication of these findings comes from comparing chlorophyll concentration with photosynthetic capacity. Hull and Leonard (1964 b) reported chlorophyll concentrations for host foliage, four species of Phoradendron, and six species (present taxonomic designation) of dwarf mistletoes. Total chlorophyll concentration for dwarf mistletoes was twelve percent to twenty-four percent that of the hosts and fifteen percent to fifty-two percent that of Phoradendron species. Phoradendron was found to fix quantities of $\mathrm{CO}_{2}$ comparable to host foliage while dwarf mistletoes fixed only five to ten percent of the amount of $\mathrm{CO}_{2}$ fixed by the host (Hull and Leonard, $1964 \mathrm{~b}$ ). The photosynthetic capacity corresponds to the amount of chlorophy11 present in the mistletoe. It is reasonable on the basis of similar low chlorophyll concentrations in seeds and aerial shoots of dwarf mistletoes, to assume that the seeds will have similar low photosynthetic rates as compared to the aerial shoots.

\section{$0_{2}$ CONSUMPIION IN LIGHT AND IN DARK}

$0_{2}$ consumption in light and in dark by seeds of $A_{\text {. }}$ campylopodum was measured by manometric and polarographic methods. These seeds 
were imbibed ten days before and had germinated three days prior to use. Data from manometric measurements is compiled in Table VIII. The data were analyzed using one way analysis of variance. The mean value for $\mathrm{O}_{2}$ consumption in the dark was $352 \mu \mathrm{O}_{2} \mathrm{~g}^{-1} \mathrm{~h}^{-1}$ and in the light was $201 \mu l \mathrm{O}_{2} \mathrm{~g}^{-1} \mathrm{~h}^{-1}$. The statistical test showed a significant difference between the resultant means of the two treatments. Figure 3 displays the results of the experiments on March 23, 1978, in graphical form. Rates were linear during the experiment.

The results from the polarographie method are in agreement with those above. The mean $0_{2}$ consumption in the dark is $353 \mu 1 O_{2} g^{-1} h^{-1}$ and in the light, $214 \mu 1 \mathrm{O}_{2} \mathrm{~g}^{-1} \mathrm{~h}^{-1}$. The data is reported in Table IX. These two values are significantly different at the 0.05 level of significance.

One explanation for the difference in $\mathrm{O}_{2}$ consumption in light and dark is that the difference is due to $0_{2}$ evolved through photosynthesis. If this is true, the difference would equal the apparent photosynthetic rate. Subtracting the mean light $\mathrm{O}_{2}$ consumption rate from the mean dark $0_{2}$ consumption rate gives the mean apparent photosynthetic rate of $151 \mu \mathrm{O}_{2} \mathrm{~g}^{-1} \mathrm{~h}^{-1}$, which is equivalent to $42.9 \%$ of the $0_{2} \mathrm{~g}^{-1} \mathrm{~h}^{-1}$ consumed during respiration. Miller (1975) used similar reasoning, attributing the difference between light and dark rates of $\mathrm{CO}_{2}$ evolution by aerial shoot tissue to photosynthesis. He found that the aerial shoots evolved $301 \mu \mathrm{CO}_{2} \mathrm{~g}^{-1} \mathrm{~h}^{-1}$ in the dark and $213 \mu \mathrm{l} \mathrm{CO}_{2}$ $\mathrm{g}^{-1} \mathrm{~h}^{-1}$ in the 1ight. The difference of $88 \mu \mathrm{Co}_{2} \mathrm{~g}^{-1} \mathrm{~h}^{-1}$ being the apparent photosynthetic rate, which is less than the rate, $151 \mu l 0_{2}$

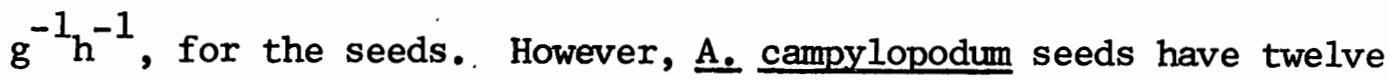




\section{TABLE VIII}

\section{$0_{2}$ UPTAKE BY SEEDS OF A. CAMPYLOPODUM IN LIGHT AND DARK MEASURED BY MANOMETRIC METHODS}

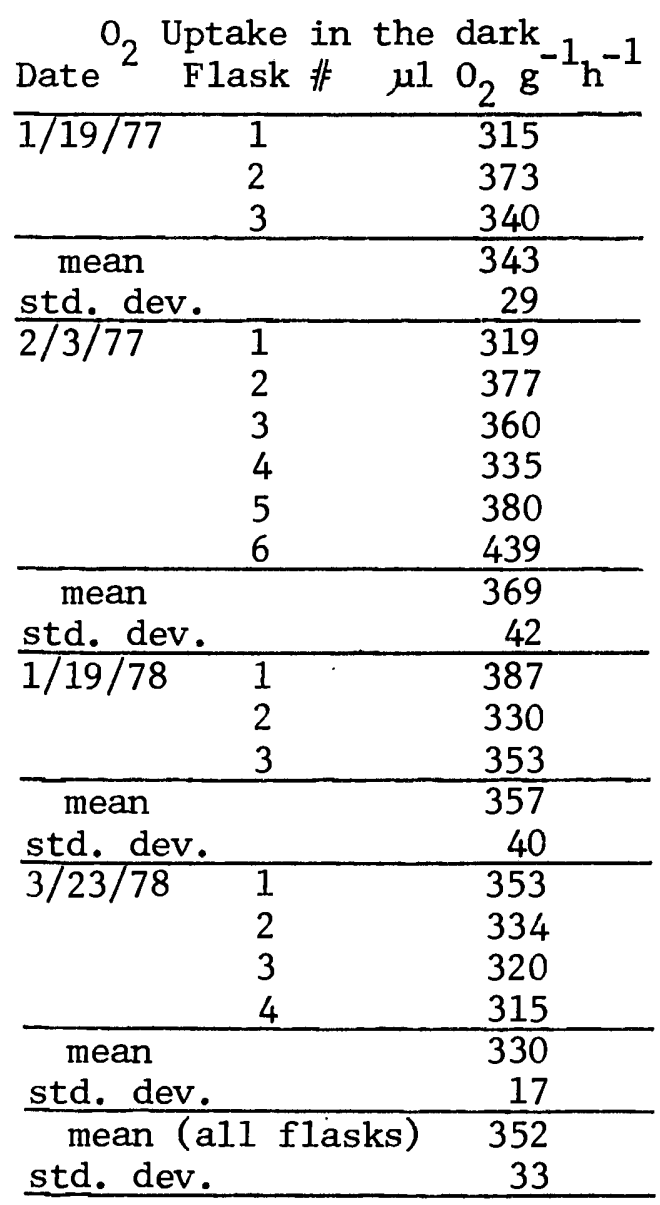

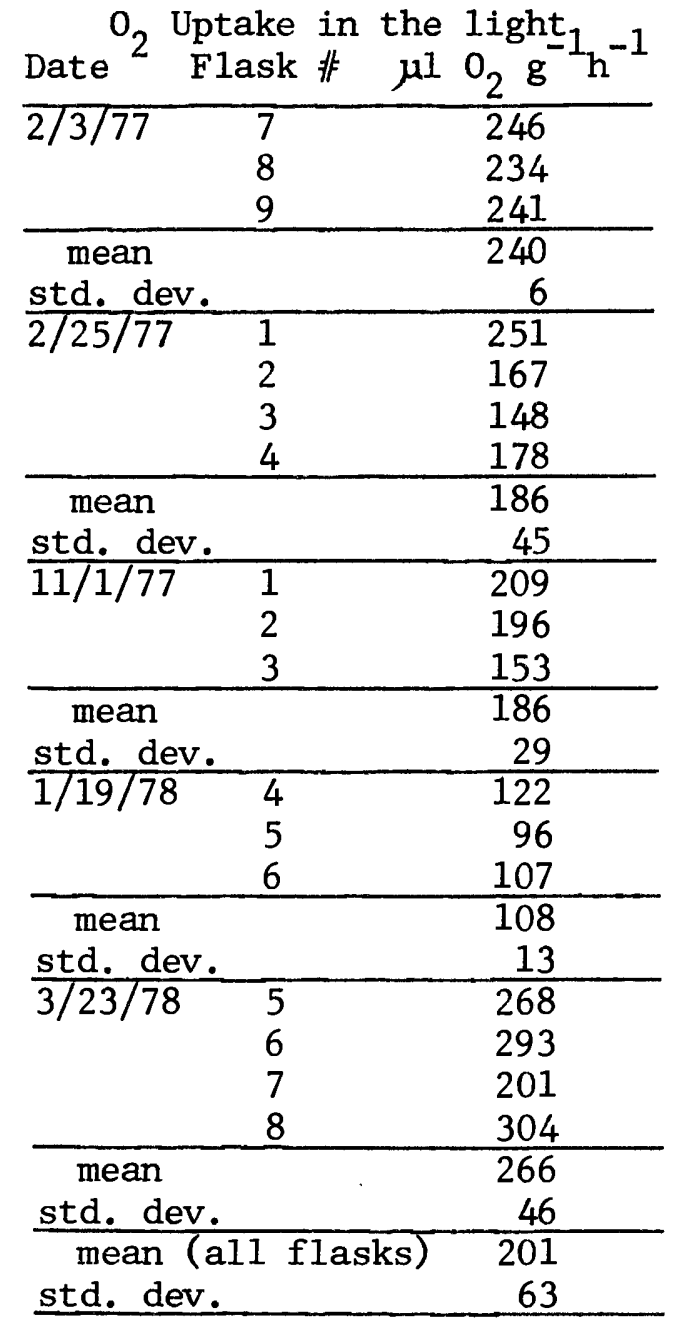




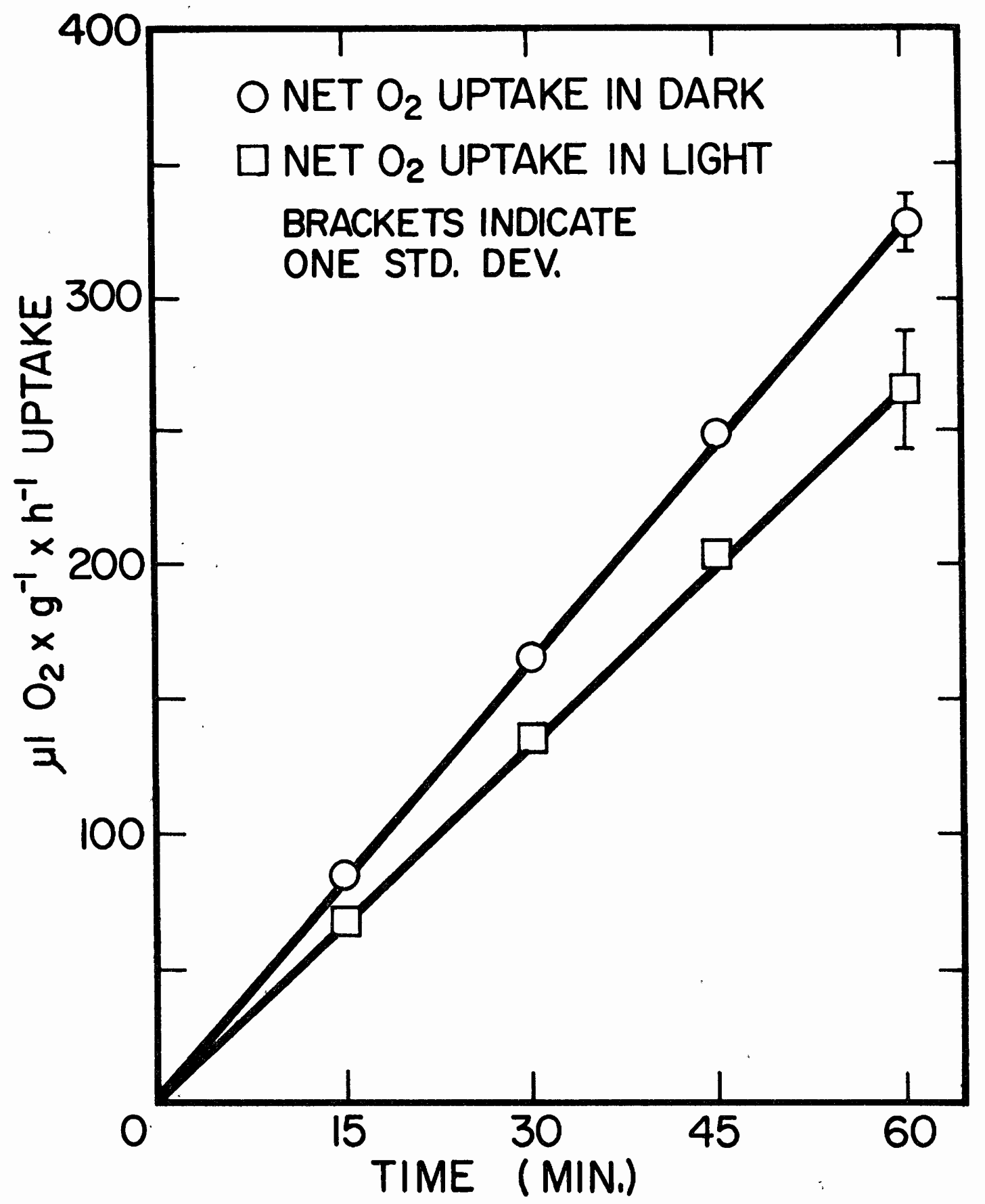

EACH POINT ON THE GRAPH REPRESENTS THE MEAN OF FOUR FLASKS CONTAINING TEN SEEDS. 3/23/78

Figure 3. $\mathrm{O}_{2}$ uptake in light and in dark by seeds of A. campylopodum. 
TABLE IX

$0_{2}$ UPTAKE BY SEEDS OF A. CAMPYLOPODUM IN LIGHT AND IN DARK MEASURED

BY POLAROGRAPHIC METHODS

$\mathrm{O}_{2}$ UPTAKE IN THE DARK

\begin{tabular}{cc} 
SAMPLE* & $0_{2} * *$ \\
\hline 1 & UPTAKE $\left(\mu 10_{2} \mathrm{~g}^{-1} \mathrm{~h}^{-1}\right)$ \\
\hline 2 & 343 \\
3 & 376 \\
4 & 352 \\
\hline mean & 342 \\
\hline std & 353.3 \\
\hline
\end{tabular}

std: dev.

$0_{2}$ UPTAKE IN THE LIGHT

SAMPLE* $0_{2}^{* *}$ UPTAKE $\left(\mu \mathrm{l} \mathrm{o}_{2} \mathrm{~g}^{-1} \mathrm{~h}^{-1}\right)$

\begin{tabular}{cc}
\hline 1 & 229 \\
2 & 235 \\
3 & 220 \\
4 & 171 \\
\hline mean & 213.8 \\
std. dev. & 29.2 \\
\hline
\end{tabular}

* Each sample consisted of 5 seeds

**: Each value reported is calculated from the average of two $15 \mathrm{~min}$. measurements 
percent more chlorophyll than $\underline{A}$. tsugense.

The respiration rate of $350 \mu \mathrm{O}_{2} \mathrm{~g}^{-1} \mathrm{~h}^{-1}$ is equivalent to 0.688 mg $\mathrm{CO}_{2} \mathrm{~g}^{-1} \mathrm{~h}^{-1}$ if one assumes a $\mathrm{RQ}$ of 1.0. This value can be converted to a per seed basis by multiplying it times $0.003 \mathrm{~g} / \mathrm{seed}$ (empirically derived) which equals $0.002 \mathrm{mg} \mathrm{CO}$ seed $^{-1} \mathrm{~h}^{-1}$. Thus if one assumes a constant respiration rate during twenty-four hours the seed would lose $.048 \mathrm{mg} \mathrm{CO}{ }_{2}$ or $1.6 \%$ of its weight. If one assumes twelve hours of light, the seed would be able to fix $0.010 \mathrm{mg}$ of $\mathrm{CO}_{2}$ (at $0.0084 \mathrm{mg} \mathrm{CO}_{2}$ seed $^{-1} \mathrm{~h}^{-1}$ ) or twenty-one percent of the $\mathrm{CO}_{2}$ expelled during respiration. Photosynthetic carbon fixation increases the effieiency of the seeds' nutrition and may provide the fine difference between life and death.

\section{${ }^{14} \mathrm{CO}_{2}$ INCORPORATION BY SEEDS OF $\underline{\text { A }} \underline{\text { CAMPYLOPODUM }}$}

The results from ${ }^{14} \mathrm{CO}_{2}$ labelling of seeds in light and in dark and subsequent analysis of location of ${ }^{14} \mathrm{C}$ are reported in Table $\mathrm{X}$ and

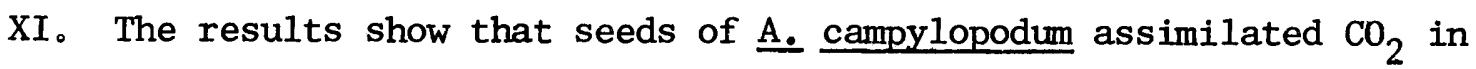
light. $\mathrm{CO}_{2}$ assimilation in the light was approximately 350 times $\mathrm{CO}_{2}$ assimilation in the dark. The seeds in light incorporated twenty-five percent of the original ${ }^{14} \mathrm{CO}_{2}$ present in the reaction flask during twenty-four hours. However, it should be remembered that the seeds are respiring at a greater rate than they are photosynthesizing thus in the course of twenty-four hours substantial dilution of the labelled ${ }^{14} \mathrm{CO}_{2}$ took place. Therefore, quantification of photosynthetic rates of the seeds by this method is not reliable.

Extraction of seeds with ethanol showed that $97-99 \%$ of the 


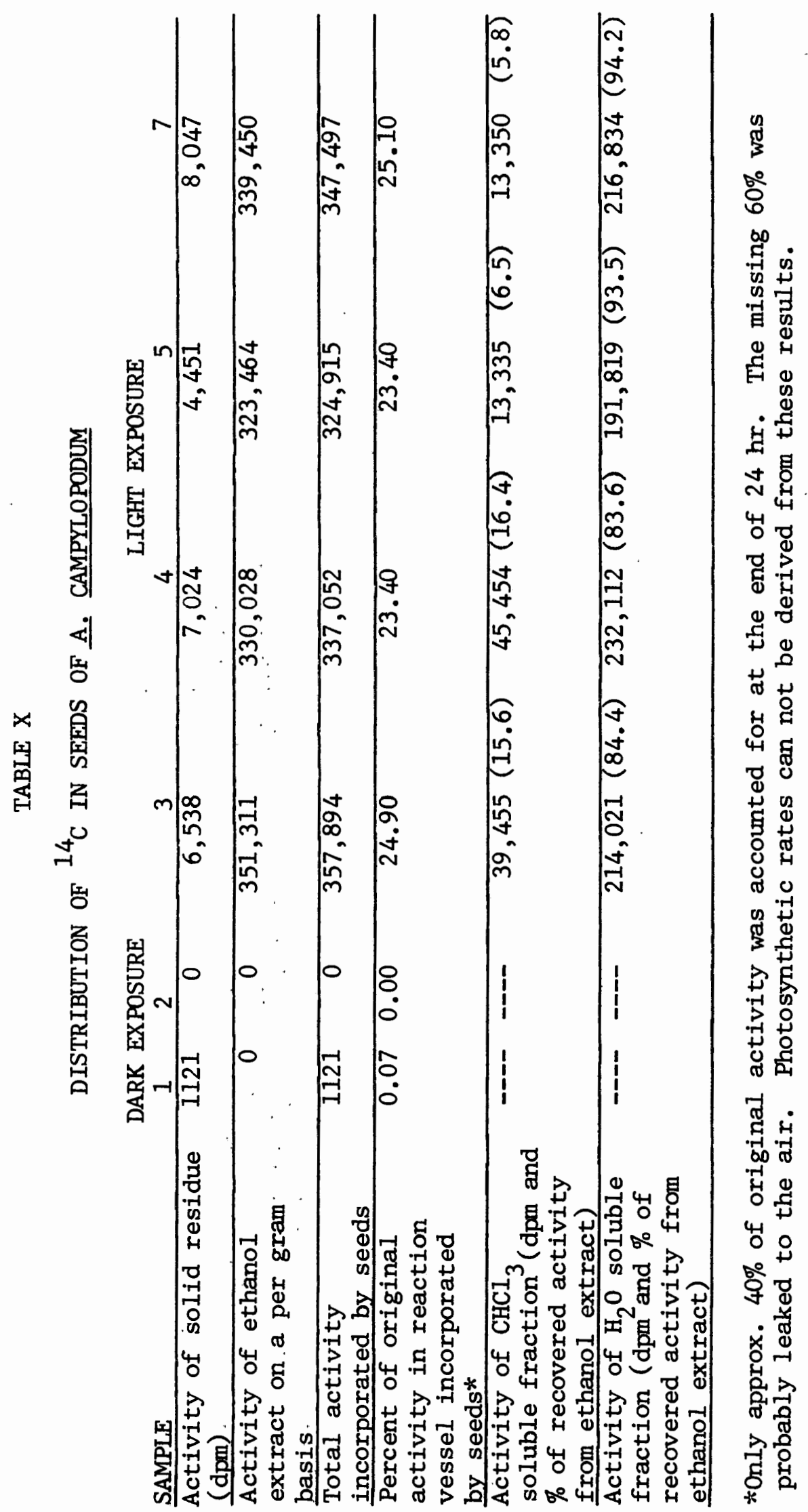




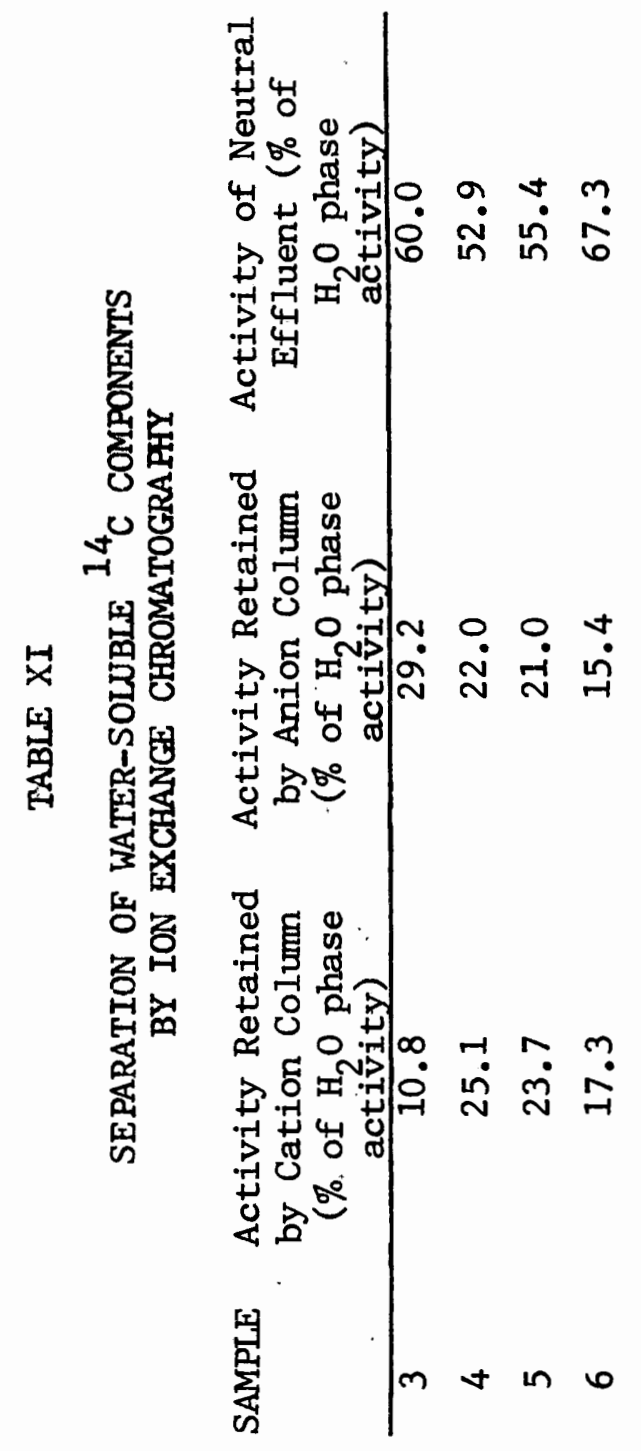


incorporated ${ }^{14} \mathrm{C}$ was ethanol soluble, of this, $83-90 \%$ of the activity in the ethanol extracts concentrate was $\mathrm{H}_{2} \mathrm{O}$ soluble. The $\mathrm{H}_{2} \mathrm{O}$ soluble phase was separated into cationic, anionic, and neutral fractions by ion exchange chromatography. These results are also reported in Table XI. The majority (50-67\%) of the label remained in the neutral fraction, while 11 to $25 \%$ of the label was in the cationic fraction, and 15 to $29 \%$ of the label was in the anionic fraction.

Miller and Tocher reported the following values from ion exchange chromatography of water soluble ${ }^{14} \mathrm{C}$ from aerial shoots: cationic fraction, 12-26\%; anionic fraction, 20-25\%; and neutra1 fraction, 51-68\%。 Hull and Leonard (1964 b) reported a smaller percentage (one percent) of label in the cationic fraction, and a larger percentage $(36-70 \%)$ in the anionic fraction. They suggested the presence of Crassulacean acid metabolism (CAM) or of enzymes active in CAM in aerial shoots based on the large amounts of ${ }^{14} \mathrm{C}$ label incorporated into malic acid. The nonexistant to very minute assimilation of ${ }^{14} \mathrm{C}$ by the seeds of $\underline{\mathrm{A}}$. campylopodum in the dark suggests the absence of CAM.

Tainter suggests that chloroplasts of A. pusillum resembled chloroplasts associated with $\mathrm{C} 4$ carbon assimilation systems. The $\mathrm{C} 4$ pathway is usually associated with a certain type of cell anatomy within leaves. Mesophyll cells have chloroplasts which fix $\mathrm{CO}_{2}$ by $\mathrm{PEP}$ carboxylase to form malate. The malate is either directly transferred or is aminated to form aspartate and then transferred to the bundle sheath cells. In the bundle sheath cells the $\mathrm{CO}_{2}$ carrier is decarboxylated. The $\mathrm{CO}_{2}$ is then fixed in the chloroplast via the Calvin cycle 
(Bonner and Varner, 1976). This elaborate anatomy has not been reported to occur in dwarf mistletoes, however, that does not exclude the possibility of the presence of $\mathrm{C} 4$ system enzymes. It is apparent that further investigation of the pathway of carbon fixation in the seed is needed. 


\section{CONCLUSION}

Seeds of A. campylopodum were quite vulnerable to fungal attack during incubation in the laboratory. Presoaking of seeds with two and three percent $\mathrm{H}_{2} \mathrm{O}_{2}$ resulted in less fungal contamination and in relatively high germination percentages as compared to results obtalned using Chlorox pretreatments. The seeds were found to contain chlorophyll in concentrations $(0.25$ to $0.40 \mathrm{mg} / \mathrm{g}$ fresh weight) comparable to those in aerial shoots which are ten to twenty percent the amounts found in host leaves (Hull and Leonard, 1964 b). The variance in chlorophyll concentrations in seeds and aerial shoots of different species supports the hypothesis of Miller and Tocher (1975) that different species of Arceuthobium vary in their dependence upon the host.

$\mathrm{O}_{2}$ consumption by seeds in $\mathrm{light}$ and in dark was measured by manometric and polarographic methods. The resulting data showed good agreement. The difference between the light and dark rates was attributed to $\mathrm{O}_{2}$ evolved during photosynthesis. This mean difference equaled $152 \mathrm{\mu l}^{\mathrm{O}} \mathrm{O}_{2} \mathrm{~g}^{-1} \mathrm{~h}^{-1}$. This figure equaled $42 \%$ of the dark respiration rate of $352 \mu 10_{2} \mathrm{~g}^{-1} \mathrm{~h}^{-1}$. The ${ }^{14} \mathrm{C}$ labelling experiments proved that the seeds fix $\mathrm{CO}_{2}$ in the light. This $\mathrm{CO}_{2}$ fixation in light supports the previous reasoning that the difference between $\mathrm{O}_{2}$ uptake in the light and in the dark was attributed to $\mathrm{O}_{2}$ evolved in the light reactions of photosyntheses. Further investigation of the pathway of $\mathrm{CO}_{2}$ fixation in seeds and shoots of dwarf mistletoe is warranted. This study supports the earlier hypothesis of Cohen (1964), Kuijt 
(1969), and Scharpf (1970), that the chlorophy11 present in dwarf mistletoe seeds is functional. However Kuijt (1969) appears to have been overly enthusiastic in his description of Viscacean seeds as "seats of great photosynthetic activity." 


\section{REFERENCES}

Anonymous 1966. Liquid scintillation counting. Nuclear-Chicago Pub. 711580 .

Anonymous 1969. Instructions for YSI model 53 biological oxygen monitor. Yellow Springs Instrument Co., Ino. Pub. A-05212.

Beckman, K. M. 1964. Physical factors affecting longevity and germination of seed of western dwarf mistletoe. Ph.D. Thesis Oregon State University, Corvallis.

Beckman, K. and L. F. Roth 1968. The influence of temperature and longevity and germination of seed of western dwarf mistletoe. Phytopathology $58: 147-150$.

Bonga, J. M. 1965. Arceuthobium pusillum Peck: Collection of seeds and in vitro culture of the early seedling stage. Can. J. Bot. $43: 1307-1308$.

Bonga, J. M. 1972. Arceuthobium pusillum: moisture requirements for germination and radicle growth Can. J. Bot. 50:2143-2147.

Bonner, J. and J. E. Varner 1976. Plant biochemistry. Third edition. Academic Press, New York.

Childs, T. W. and K. R. Shea 1967. Annual losses from disease in Pacific Northwest forests. U. S. For. Serv. Resource Bulletin PNW-20.

Cohen, L. Q. 1963. Studies on the ontogeny of the dwarf mistletoes. Arceuthobium II homology of the endophytic system. Amer. J. Bot. 50:409-417.

Dodge, J. D. and G. B. Lawes 1974. Plastid ultrastructure in some parasites and semi-parasite plants. Cytobrologie 9:1701

Hawksworth, H. G. and D. Wiens 1972. Biology and classification of dwarf mistletoes (Arceuthobium). USDA Handbook No. 401. Washington, D. C.

Holden, M. 1965. Chlorophylls, in Chemistry and biochemistry of plant pigments, edited by T. W. Goodwin. Academic Press. New York.

Hull, R. J. and 0. A. Leonard 1964. Physiological aspects of parasitism in mistletoes (Arceuthobium and Phoradendron). 
REFERENCFS (CONT.)

Hull, R. J. and O. A. Leonard 1964a. I. The carbohydrate nutrition of mistletoe. Plant Physiol. 39:996-1007.

and

1964b. II. The photosynthetic capacity of mistletoe. Flant Physiol. 39:1008-1017.

Kuijt, J. 1969. The biology of parasitic flowering plants. Universit University of California Press. Berkeley.

Knutson, D. M. 1971. Dwarf mistletoe seed storage best at low temperature and high relative humidity. USDA Forest Service Research Note PNW 145-71.

Knutson, D. M. 1974. Infection technique and seedling response to dwarf mistletoes. Plant Disease Reporter 58:3:235-238.

Miller, J。R. 1973. Photosynthesis and respiration of Arceuthobium tsugense. M.S. Thesis, Portland State University, Portland.

Miller, J. R. and R. D. Tocher 1975. Photosynthesis and respiration of Arceuthobium tsugense (Loranthoceae). Amer. J. Bot. $62: 765-769$.

Muir, J. A. 1975. Photosynthesis by dwarf mistletoe seeds. Bi-monthly research notes Environment Canada Forestry Service 31:17 Edmonton, Alberta.

Rediske, J. Ho and K. R. Shea 1961. The production and translocation of photosynthate in dwarf mistletoe and lodgepole pine. Amer. J. Bot. $48: 447-452$.

Rohlf, F. J. and R. R. Sokal 1969. Statistical tables. W. H. Freeman and Co., San Francisco.

Scharpf, R. F. and J. R. Parmeter Jr. 1962. The collection, storage, and germination of seeds of a dwarf mistletoe. J. Forest. $60: 551-552$

Scharpf, R. F. 1970. Seed viability, germination, and radicle growth of dwarf mistletoe in California. USDA Forest Serv. Res. Pap. PSW-59. Berkeley, Calif.

Sestak, Z. Catsky, J. and P. G. Jarvis 1971. Plant photosynthetic production, manual of methods. Dr. W. Junk, N. V. Pub. The Hague.

Sokal, R. R. and F. J. Rohlf 1969. Biometry. W. H. Freeman and Co., San Francisco. 


\section{REFERENCES (CONT.)}

Tainter, F. H. 1971. The ultrastructure of Arceuthobium pusillum. Can. J. Bot. $49: 1615-1622$.

Umbreit, W. Wo, Burris, R. H., and J. F. Stauffer 1959. Manometric techniques. Burgess Pub. Minneapolis.

Vernon, L. P. and G. R. Seely 1966. The chlorophylls. Academic Press. New York.

Wang, C. H. and D. L. Willis 1965. Radiotracer methodology in blological science. Prentice-Hall, Inc. Englewood Cliffs, New Jersey.

Wharton, D. and R. E. McCarty 1972. Experiments and methods in biochemistry. Macmillan Pub. Co.,. New York.

Wicker, E. F. 1974. Ecology of dwarf mistletoe seed. USDA Forest Serv. Res. Pap. INT-154 Ogden, Utah.

Zozlowski, T. T. editor 1972. Seed Biology.

1972. Vol. I. Importance, development, and germination. Academic Press. New York.

1972. Vo1. II. Germination control, metabolism and pathology. Academic Press. New York.

1972. Vol. III Insects, and Seed collection, storage testing and certification. Academic Préss. New York. 


\section{APPENDIX}

TABLE XII

COMPARISON OF GERMINATION RATES BETWEEN YEARS BY PRETREATMENTS ANOVA TABLE $1 \% \mathrm{H}_{2} \mathrm{O}_{2}$ PRETREATMENT

\begin{tabular}{lrrrrr} 
SOURCE & DF & \multicolumn{1}{c}{ SS } & MS & F & F(.05) \\
\hline TREATMENT & 2 & 2130.7143 & 1065.3571 & 16.90 & 3.98 \\
ERROR & 11 & 693.0000 & 63.0000 & & \\
\hline TOTAL & 13 & 2823.7143 & &
\end{tabular}

ANOVA TABLE $2 \% \mathrm{H}_{2} \mathrm{O}_{2}$ PRETREATMENT

\begin{tabular}{lrrrrr} 
SOURCE & DF & \multicolumn{1}{l}{ SS } & MS & F & F $(.05)$ \\
TREATMENT & 2 & 3842.6286 & 1921.3143 & 37.15 & 3.98 \\
ERROR & 11 & 568.8000 & 51.7091 & & \\
\hline TOTAL & 13 & 4411.4286 & & &
\end{tabular}

ANOVA TABLE $3 \% \mathrm{H}_{2} \mathrm{O}_{2}$ PRETREATMENT

\begin{tabular}{lrrrrr} 
SOURCE & DF & \multicolumn{1}{c}{ SS } & MS & F & F(.05) \\
\hline TREATMENT & 2 & 4333.2071 & 2166.6036 & 36.04 & 3.98 \\
ERROR & 11 & 661.1500 & 60.1045 & & \\
\hline TOTAL & 13 & 4994.3571 & & &
\end{tabular}

RANKED TREATMENT MEANS*

\begin{tabular}{|c|c|c|c|c|c|}
\hline TREATMENT & MEANS & TREATMENT & MEANS & TREATMENT & MEANS \\
\hline $\begin{array}{l}1976-1 \% \\
1975-1 \%\end{array}$ & $\begin{array}{l}2000 \\
5000\end{array}$ & $\begin{array}{l}1976-2 \% \\
1975-2 \%\end{array}$ & $\begin{array}{l}50.2000 \\
30.0000\end{array}$ & $\begin{array}{l}1976-3 \% \\
1975-3 \%\end{array}$ & $\begin{array}{l}53.4000 \\
25.2500\end{array}$ \\
\hline $1977=$ & 00 & $1977-2 \%$ & 11.000 & 1977 & 12.6000 \\
\hline
\end{tabular}

*Analysis using SNK tests showed no significant difference at the 0.05 level of sienificance between values connected by vertical lines.

DF . = degrees of freedom

SS $\quad$ = sum squares

MS $\quad=$ mean squares

$\dot{F} \quad=F$ test statistic

$F(.05)=$ critical value of $F$ at the .05 level of significance 
TABLE XIII

COMPARISON OF GERMINATION RATES FROM PRETREATMENTS OF SEEDS WITH 3

SOLUTIONS $(1 \%, 2 \%, 3 \%)$

OF $\mathrm{H}_{2} \mathrm{O}_{2}$ BY YEAR

ANOVA TABLE 1975

\begin{tabular}{lrrrrr} 
SOURCE & DF & \multicolumn{1}{l}{ SS } & MS & F & F(.05) \\
\hline TREATMENT & 2 & 568.5000 & 284.2500 & 9.925 & 4.256 \\
ERROR & 9 & 257.7500 & 28.6389 & & \\
\hline TOTAL & 11 & 826.2500 & & &
\end{tabular}

ANOVA TABLE 1976

\begin{tabular}{lrrrrr} 
SOURCE & DF & \multicolumn{1}{c}{ SS } & MS & F & F(.05) \\
\hline TREATMENT & 2 & 836.8000 & 418.4000 & 3.144 & 3.890 \\
ERROR & 12 & 1596.8000 & 133.0667 & & \\
\hline TOTAL & 14 & 2433.6000 & & &
\end{tabular}

ANOVA TABLE 1977

\begin{tabular}{lrrrrr} 
SOURCE & DF & \multicolumn{1}{c}{ SS } & MS & F & F(.05) \\
\hline TREATMENT & 2 & 40.5333 & 20.2667 & 2.520 & 3.890 \\
ERROR & 12 & 96.4000 & 8.0333 & & \\
\hline TOTAL & 14 & 136.9333 & & &
\end{tabular}

\section{RANKED TREATMENT MEANS*}

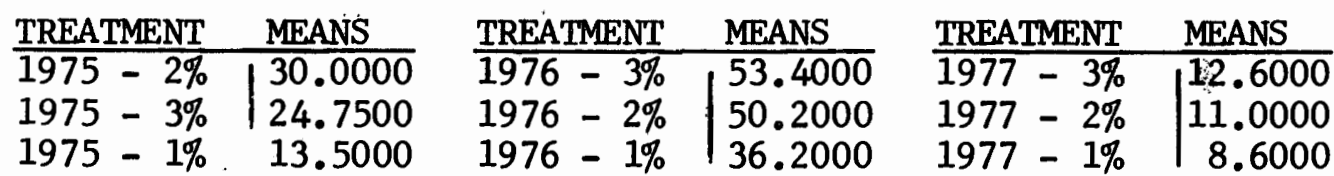

*Analysis using SNK tests showed no significant difference at the 0.05 level of significance between values connected by vertical lines. 
TABLE XIV

GERMINATION RATES OF SEEDS OF

A. CAMPYLOPODUM PRETREATED

WITH VARIOUS SOLUTIONS

OF CHLOROX

ANOVA TABLE

\begin{tabular}{lrllll} 
SOURCE & DF & SS & MS & F & F(.05) \\
\hline TREATMENT & 4 & 348.9333 & 87.2333 & 1.51 & 3.48 \\
ERROR & 10 & 576.6667 & 57.6667 & & \\
\hline TOTAL & 14 & 925.6000 & & &
\end{tabular}

RANK TREATMENT MEANS

\begin{tabular}{l|r} 
TREATMENT & MEANS \\
\hline $1976-1 \%$ & 20.0000 \\
$1976-2 \%$ & 15.3333 \\
$1976-3 \%$ & 11.6667 \\
$1976-4 \%$ & 8.3333 \\
$1976-5 \%$ & 6.6667
\end{tabular}

*Analysis using SNK tests showed no significant difference at the 0.05 level of significance between values connected by vertical lines. 
TABLE XV

ANOVA TABLE CHLOROPHYLL CONCENTRATIONS

IN AERIAL SHOOTS AND SEEDS OF 4

SPECIES OF DWARF MISTLETOE

\begin{tabular}{llllll} 
SOURCE & DF & SS & MS & F & F(.05) \\
\hline TREATMENT & 7 & 0.0402 & 0.0057 & 19.0 & 3.61 \\
ERROR & 17 & 0.0050 & 0.0003 & & \\
\hline TOTAL & 24 & 0.0452 & & &
\end{tabular}

\section{RANKED TREATMENT MEANS*}

TREATMENT MEANS

$\mathrm{A}_{0} \mathrm{~d}_{0}$ seeds 0.39

A $\mathrm{A}_{0}$ d.

A. $\bar{c}_{0}$ shoots 0.36

A. d. shoots 0.35

A. c. seeds 0.34

A. d. seeds 0.31

A. t. shoots 0.31

$\underline{A_{0}} \underline{t_{0}}$ seeds 0.25

*Analysis using SNK test showed no significant difference at the 0.05 level of significance between values connected by vertical lines. 
TABLE XVI

ANOVA TABLE 0 , UPTAKE BY SEEDS

OF A. CAMPYLOPODUM MEASURED

BY MANOMETRIC METHODS

\begin{tabular}{lrrrrr} 
SOURCE & DF & \multicolumn{1}{l}{ SS } & MS & F & F(.05) \\
\hline TREATMENT & 1 & 188828.8471 & 188828.8471 & 72.58 & 4.16 \\
ERROR & 31 & 80646.2481 & 2601.4919 & & \\
\hline TOTAL & 32 & 269475.0952 & &
\end{tabular}

RANK TREATMENT MEANS

TREATMENT

\begin{tabular}{lll}
\hline $\mathrm{O}_{2}$ uptake in dark & $\frac{\text { M }}{352.1937}$ \\
$\mathrm{O}_{2}$ uptake in light & 200.8353
\end{tabular}

TABLE XVII

ANOVA TABLE $0_{2}$ UPTAKE BY SEEDS OF

A. CAMPYLOPODUM MEASURED BY

POLAROGRAFHIC METHODS

\begin{tabular}{lrrrrr} 
SOURCE & DF & \multicolumn{1}{c}{ SS } & MS & F & F(.05) \\
TREATMENT & 1 & 39200.0 & 39200.00 & 83.99 & 5.99 \\
ERROR & 6 & 2800.0 & 466.67 & & \\
\hline TOTAL & 7 & 42000.0 & &
\end{tabular}

RANK TREATMENT MEANS

TREATMENT

$\mathrm{O}_{2}$ uptake in dark $\quad \frac{\mathrm{M}}{352.19}$

$\begin{array}{ll}\mathrm{O}_{2} \text { uptake in dark } & 352.19 \\ \mathrm{O}_{2} \text { uptake in light } & 200.84\end{array}$ 